\title{
WestVirginiaUniversity
}

THE RESEARCH REPOSITORY @ WVU

Graduate Theses, Dissertations, and Problem Reports

2009

\section{Habitat selection and predation risk in larval lampreys}

Dustin M. Smith

West Virginia University

Follow this and additional works at: https://researchrepository.wvu.edu/etd

\section{Recommended Citation}

Smith, Dustin M., "Habitat selection and predation risk in larval lampreys" (2009). Graduate Theses, Dissertations, and Problem Reports. 2805.

https://researchrepository.wvu.edu/etd/2805

This Thesis is protected by copyright and/or related rights. It has been brought to you by the The Research Repository @ WVU with permission from the rights-holder(s). You are free to use this Thesis in any way that is permitted by the copyright and related rights legislation that applies to your use. For other uses you must obtain permission from the rights-holder(s) directly, unless additional rights are indicated by a Creative Commons license in the record and/ or on the work itself. This Thesis has been accepted for inclusion in WVU Graduate Theses, Dissertations, and Problem Reports collection by an authorized administrator of The Research Repository @ WVU. For more information, please contact researchrepository@mail.wvu.edu. 
Habitat Selection and Predation Risk in Larval Lampreys

Dustin M. Smith

\author{
Thesis submitted to the \\ Davis College of Agriculture, Forestry, and Consumer Sciences \\ at West Virginia University \\ in partial fulfillment of the requirements \\ for the degree of \\ Master of Science \\ in \\ Wildlife and Fisheries Resources
}

Stuart A. Welsh, Ph. D., Chair

Kyle J. Hartman, Ph. D.

Daniel A. Cincotta, M. S.

Division of Forestry and Natural Resources

Morgantown, WV

2009

Key Words: Lampetra aepyptera, least brook lamprey, ammocoete, habitat selection, predator avoidance 


\section{Abstract \\ Habitat Selection and Predation Risk in Larval Lampreys \\ Dustin M. Smith}

This thesis examines habitat preference and the influence of habitat on predation of larvae (ammocoetes) of the least brook lamprey (Lampetra aepyptera). The thesis comprises three chapters: (1) an introduction and literature review on the general life history of lampreys and on studies related to ammocoetes and their habitat, (2) an experimental study of habitat preference in ammocoetes of the least brook lamprey, and (3) an experimental study of the relationship between habitat availability and predation risk in ammocoetes. For the first study, we quantified substrate selection in small $(<50 \mathrm{~mm})$ and large $(100-150 \mathrm{~mm})$ ammocoetes of the least brook lamprey. In aquaria, ammocoetes were given a choice to burrow into six equallyavailable substrate types: small gravel $(2.36-4.75 \mathrm{~mm})$, coarse sand $(0.5-1.4 \mathrm{~mm})$, fine sand (0.125-0.5 mm), organic debris (approximately 70\% decomposing leaves and stems, $15 \%$ silt, and $15 \%$ sand), an even mixture of silt, clay, and fine sand, and silt/clay $(<0.063 \mathrm{~mm})$. Fine sand was selected with a significantly higher probability than any other substrate. In the second study, we experimentally examined the influence of habitat availability on predation risk of ammocoetes. Ammocoetes were placed in aquaria containing a predator species (yellow bullhead, Ameiurus natalis) and one of 3 substrates: fine sand $(0.125-0.5 \mathrm{~mm})$, coarse sand $(0.5-1.4 \mathrm{~mm})$, or silt/clay $(<0.063 \mathrm{~mm})$. Use of the three substrate types was based on a previous experiment where fine sand was determined to be the preferred benthic habitat of least brook lamprey. Based on 10 trials with each habitat type, survival of ammocoetes was highest in aquaria with fine sand (mean = $80 \%$ ), and lower in those with coarse sand $($ mean $=58 \%$ ) and silt/clay $($ mean $=4 \%)$. The results of both studies conducted indicate that populations of least brook lamprey ammocoetes may be limited by the availability of fine sand habitat. The first study indicated that least brook lamprey ammocoetes are habitat specialists, preferring substrates composed primarily of fine sand. The second study showed that the availability of fine sand habitat may influence the predation risk of ammocoetes, as ammocoete survival from predation was highest in fine sand, and lower in other substrates. 


\section{Acknowledgments}

I would like to thank Dr. Stuart Welsh, the WVU Division of Forestry and Natural Resources, and the USGS Cooperative Fish and Wildlife Research Unit for allowing me the opportunity to attend graduate school and be a part of this very interesting study. I must extend a special thanks to Dr. Stuart Welsh for the support, guidance, and infinite words of wisdom provided throughout my time here. Thanks also go to Dr. Kyle Hartman and Dan Cincotta for serving on my committee and for their useful suggestions along the way. A special thanks goes to Dan Cincotta for introducing me to the field of ichthyology and to the fascinating world of non-game fishes. Additionally, I would like to thank the WVU Department of Biology for providing employment and teaching assistantships. I would also like to thank Dr. Philip Turk for the extensive amount of time and effort put into assisting me with the statistical process and for his statistical contributions. Additional thanks goes to J.R. Shute, P. Rakes, and C. Ruble from Conservation Fisheries, Inc., Knoxville, TN who provided design and instructions for the aquaria recirculation system (reference to trade names does not imply endorsement of commercial products by the U.S. government).

Finally, I would like to thank my family for their support and encouragement throughout my time at WVU. My Mom (Debbie), Dad (Dave), and Sister (Danielle) have always been there for me. Last but not least, I would like to thank my wife Ashley for her help in the field, in the lab, for presentation photography, and for her endless love and devotion. Without her undying support none of this would have been possible. 


\section{Table of Contents}

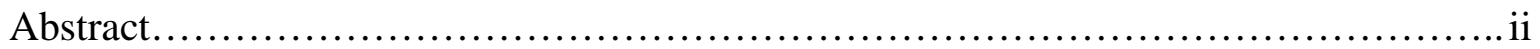

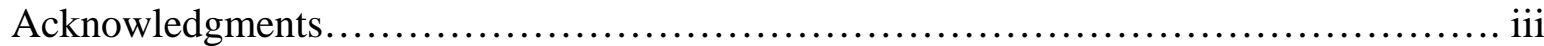

Table of Contents........................................................................... iv

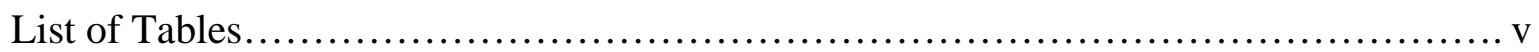

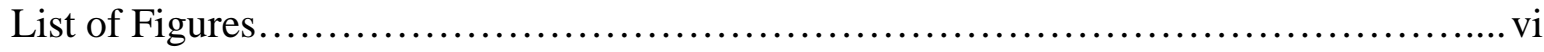

Chapter 1: Literature Review..........................................................

Ammocoete Life Stage ...................................................... 2

Ammocoetes and Their Habitat.................................................. 3

Habitat Selection and Susceptibility to Predation.................................. 7

Literature Cited............................................................... 10

Chapter 2: Selection and Preference of Benthic Habitat by Larval Lampreys............... 14

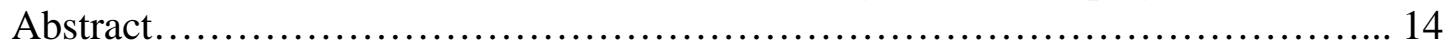

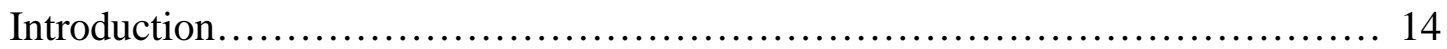

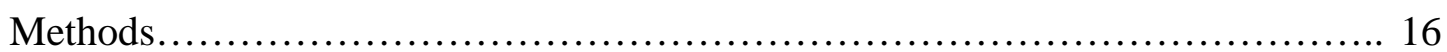

Ammocoete Collection................................................... 16

Aquaria Setup..........................................................

Experimental Design............................................... 18

Statistical Analysis.................................................... 18

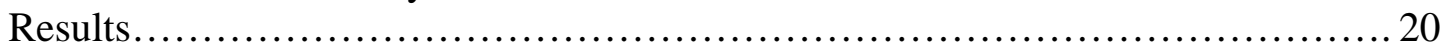

Small Ammocoete Habitat Selection.......................................220

Large Ammocoete Habitat Selection...................................... 20

Small vs. Large Ammocoete Habitat Selection............................... 21

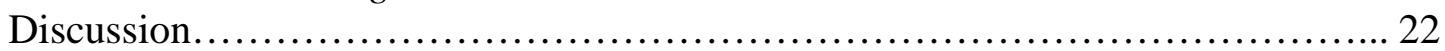

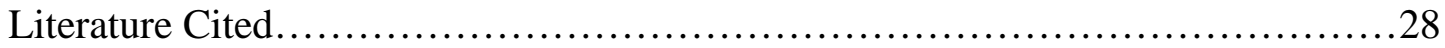

Chapter 3: The Influence of Habitat Availability on Predation Risk in Larval Lampreys... 37

Abstract......................................................................... 37

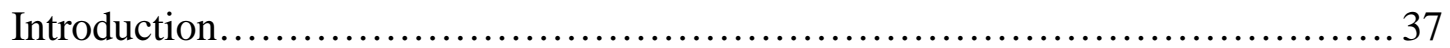

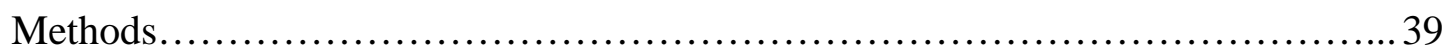

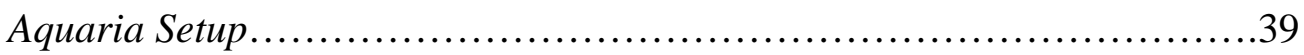

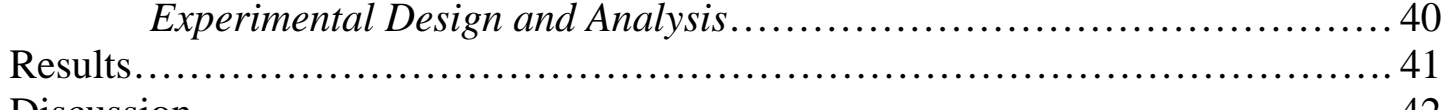

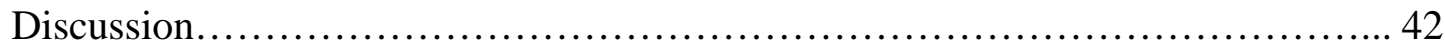

Literature Cited............................................................ 46 


\section{List of Tables}

Table 1.1. Summary of past research on larval lamprey habitat selection................. 13

Table 2.1. Total number and percentage of small and large ammocoetes selecting each

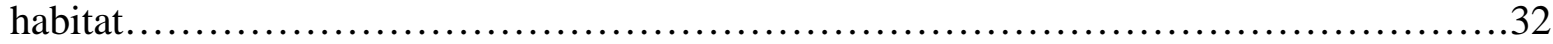

Table 2.2. Habitat selection ratios +/- 95\% CI for small and large ammocoetes........... 32

Table 2.3. Pairwise comparisons with Bonferroni $95 \%$ CIs of habitat selection for small and

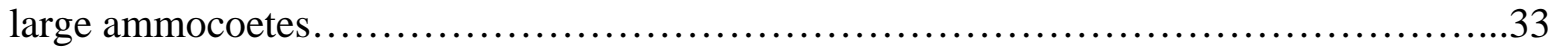

Table 2.4. Odds ratios and $95 \%$ Confidence Intervals (CI) for small vs. large ammocoete habitat

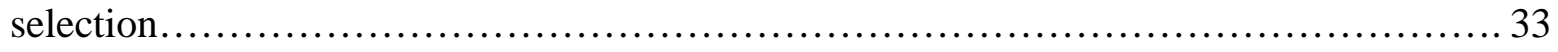

Table 3.1. Survival of ammocoetes for each habitat type...........................49

Table 3.2. Comparisons of ammocoete survival from predation in different habitat types and the odds of survival in one habitat vs. another. 49

Table 3.3. The odds of ammocoetes surviving predation in a given habitat vs. another habitat and the associated $95 \%$ confidence intervals. 


\section{List of Figures}

Figure 2.1. Percentages of small $(<50 \mathrm{~mm})$ and large $(100-150 \mathrm{~mm})$ ammocoetes that selected each equally-available habitat type. "SCS Mix" indicates the silt/clay/sand mixture habitat. Dark bars represent the \% of small ammocoetes, while white bars represent the \% of large

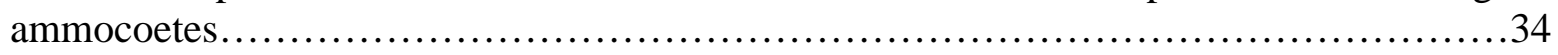

Figure 2.2. Median numbers (smallest observation, lower quartile, upper quartile, and largest observation) per trial of small ammocoetes that selected each of six equally-available habitat types. "SCS mix" represents the silt/clay/sand mixture..............................35

Figure 2.3. Median numbers (smallest observation, lower quartile, upper quartile, largest observation) per trial of large ammocoetes that selected each of six equally-available habitat types. "SCS mix" represents the silt/clay/sand mixture ............................. 36

Figure 3.1. Summary of experimental trials showing number of surviving ammocoetes in each

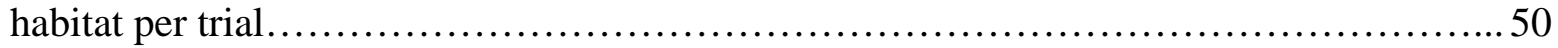

Figure 3.2. Median percentage (smallest observation, lower quartile, upper quartile, and largest observation) per trial of ammocoetes that survived each habitat type.... .51 


\section{Chapter 1: Literature Review}

This thesis examines habitat preference and the influence of habitat on predation of larvae (ammocoetes) of the least brook lamprey (Lampetra aepyptera). The thesis comprises three chapters: (1) an introduction and literature review on the general life history of lampreys and on studies related to ammocoetes and their habitat, (2) an experimental study of habitat preference in ammocoetes of the least brook lamprey, and (3) an experimental study of the relationship between habitat availability and predation risk in ammocoetes. In general, the ecology of lampreys is poorly understood with large information gaps, such as in our knowledge of habitat selection and its correlation with susceptibility to predation. Also, the relationship between habitat availability and ammocoete survival is poorly understood, and may be relevant to the management and conservation of lamprey species given a potential link between habitat loss and population declines.

Lampreys (Petromyzontidae) are a primitive group of fishes lacking jaws, scales, bone, and paired fins (Nelson 2006). Lampreys go through two distinct life stages during their lifespan, a larval or ammocoete phase and an adult phase (Moyle and Cech 2004). Ammocoetes inhabit burrows in the soft substrate of streams, whereas adults eventually exit these burrows and spawn at the head of riffles (Moyle and Cech 2004). Lampreys have an anguilliform or eel-like body shape during both ammocoete and adult life phases, and adults are either parasitic or non-parasitic (Nelson 2006). While adults of parasitic lampreys feed on blood and body fluids of host fishes, non-parasitic lampreys do not feed during adulthood (Jenkins and Burkhead 1993). Although the feeding habits of adult parasitic and non-parasitic forms differ, the ammocoetes of both groups burrow into benthic substrates and filter feed on detritus, bacteria, and algae (Moore and Potter 1974; Malmqvist and Bronmark 1981; Mallatt 1983; Sutton and Bowen 1994). 


\section{Ammocoete Life Stage}

All species of lampreys go through a distinct larval life stage lasting from 3-7+ years (Purvis 1970; Hardisty and Potter 1971; Potter 1980; Beamish and Austin 1985; Burr and Shasteen 2007). In both parasitic and non-parasitic lampreys, most of the lifespan is spent as an ammocoete (Hardisty and Potter 1971; Potter 1980; Jenkins and Burkhead 1993; Moyle and Cech 2004). The proportion of the lifespan spent as an ammocoete is greater for non-parasitic lampreys, mainly because for these lampreys, life as adults is short, lasting only 3-6 months, whereas 3-7+ years are spent as an ammocoete (Hardisty and Potter 1971; Beamish and Medland 1988; Burr and Shasteen 2007). Parasitic lampreys spend the majority of their life as ammocoetes, but have a longer adult stage lasting between $1 \frac{1}{2}-2 \frac{1}{2}$ years (Hardisty and Potter 1971). Within 1-3 weeks after hatching, ammocoetes move to slow velocity marginal areas of streams and burrow into the benthic substrate (Leach 1940; Dendy and Scott 1953; Moore and Potter 1974; Malmqvist 1980; Potter 1980; Beamish and Jebbink 1994; Beamish and Lowartz 1996; Sugiyama and Goto 2001; Mundahl et al. 2006).

Ammocoetes spend most of their larval life burrowed into the benthic substrate of streams; hence, benthic habitat is critical for ammocoete survival (Hardisty and Potter 1971; Beamish and Jebbink 1994; Beamish and Lowartz 1996; Renaud 1997; Sugiyama and Goto 2002; Torgensen and Close 2004; Mundahl et al. 2006). Ammocoetes live as suspension feeders in burrows within the soft sediment and filter feed on detritus, bacteria, and algae from surrounding water and substrate (Beamish and Austin 1985; Sutton and Bowen 1994; Beamish and Lowartz 1996). Ammocoetes line burrow walls with mucus from their glandular endostyle, and depend on a unidirectional flow of water through these burrows to receive food and uptake dissolved oxygen (Beamish and Lowartz 1996). Therefore it is considered imperative that benthic substrate size be 
small enough to create adequate burrows, but not so small as to suffocate the ammocoetes and make burrowing difficult (Beamish and Jebbink 1994; Beamish and Lowartz 1996). Ammocoetes may abandon burrows at night to search for new or better quality habitat (Hardisty and Potter 1971; Reynolds and Casterlin 1979; Potter 1980; Sugiyama and Goto 2002; Torgensen and Close 2004; Quintella et. al 2005). Benthic stream substrates such as sand, silt, organic matter, and clay, are thought by many researchers to comprise critical habitat for ammocoetes. Not only is substrate type believed to be important for the feeding of ammocoetes, it is also presumed integral in providing refuge for ammocoetes from potential predators (Hardisty and Potter 1971). Given the importance of the substrate for foraging habitat and refuge, it is likely that lampreys select specific types or combinations of substrates. The conservation and management of lamprey species requires an understanding of substrate use, given that lampreys are burrowing ammocoetes for most of their lifespan (Hardisty and Potter 1971; Moyle and Cech 2004).

\section{Ammocoetes and Their Habitat}

Given the importance of stream substrate, ammocoetes will likely select specific substrates or a combination of substrates. The importance of benthic habitat for ammocoetes is well documented in the literature. However, results of research studies are inconclusive with respect to substrate preference. Some studies on the substrate selection of ammocoetes have reported vague results or weak conclusions based on small sample sizes of observational data and few studies have looked at the substrate selection in one of the most common species, the least brook lamprey (Lampetra aepyptera).

Fine sediment particles, specifically clay and silt, are mentioned frequently in the 
literature, but results are inconsistent. Some authors have reported the importance of silt when combined with sand (Reighard and Cummins 1916; Sugiyama and Goto 2002). For example, Reighard and Cummins (1916) found larval northern brook lampreys (Ichthyomyzon fossor) in an even mixture of sand and silt. However, the authors also noted that most ammocoetes of the northern brook lamprey seemed to completely avoid clay substrates. Sugiyama and Goto (2002) also concluded that ammocoetes in general most often utilize a mixture of fine sand and silt. However, while some authors have reported the importance of silt, others have noted an avoidance of substrates with an excess of silt (Beamish and Jebbink 1994; Beamish and Lowartz 1996). One main argument for this is that silt possibly suffocates ammocoetes by compacting burrows (Beamish and Jebbink 1994; Beamish and Lowartz 1996; Renaud 1997; Torgensen and Close 2004). Some authors also report clay as an important substrate for ammocoetes because its adhesive properties maintain the integrity of ammocoete burrows (Hardisty and Potter 1971). For instance, according to Hardisty and Potter (1971), optimal ammocoete habitat generally has a large clay fraction. Their reason for believing clay to be important was because it creates "an open structured sediment” thus allowing ammocoetes to create more adequate burrows. Other authors however, argue that ammocoetes avoid clay (Reighard and Cummins 1916; Beamish and Jebbink 1994; Beamish and Lowartz 1996; Renaud 1997; Torgensen and Close 2004). In a laboratory study, Lee (1989) determined that ammocoetes of Petromyzon marinus and Lampetra appendix avoided both clay and silt particles. In general, an overabundance of either silt or clay particles could inhibit oxygen uptake in ammocoetes (Beamish and Jebbink 1994). Essentially, an overabundance of clay and silt can inhibit oxygen uptake by clogging the gill lamellae (Beamish and Lowartz 1996). Beamish and Lowartz (1996) also suggested that very small particles, such as clay and very fine silt, compact into an impenetrable barrier for burrowers and 
for water to pass through.

Other authors have emphasized ammocoete selection of fine sand (Beamish and Jebbink 1994; Beamish and Lowartz 1996; Burr and Shasteen 2007). The particle size of fine sand is small enough to make stable burrows and should not smother or suffocate the ammocoetes (Beamish and Jebbink 1994; Beamish and Lowartz 1996). Burrow stability from fine sand-sized particles provides good circulation of water through burrows allowing ammocoetes to acquire adequate amounts of dissolved oxygen and consistent opportunities to filter feed (Beamish and Jebbink 1994; Beamish and Lowartz 1996). Burr and Shasteen (2007) found least brook lamprey ammocoetes at sites mainly comprised of fine sand (80 - $90 \%)$. These data were based on field collections done in the Shawnee National Forest in southern Illinois. In a laboratory study, Lee (1989) determined that ammocoetes of Petromyzon marinus and Lampetra appendix selected for fine and medium sands. In another study, ammocoetes of the American brook lamprey (Lampetra appendix) most often selected substrates of medium/fine sand (Mundahl et al. 2006). Leach (1940) also found that most northern brook lamprey ammocoetes occupied substrates of fine sand. Another species noted to select fine and medium sand substrate was the southern brook lamprey (Ichthyomyzon gagei) (Beamish and Jebbink 1994). Finally, Beamish and Lowartz (1996) found a positive relationship between the density of American brook lamprey ammocoetes and the amount of medium-fine sand. Drawing from their results, the authors concluded that medium-fine sand is ideal for both burrowing and burrow construction and probably allows for optimum flow of water through the substrate (Beamish and Lowartz 1996).

Some authors mention that coarser substrates could possibly be too heavy for larvae to move (Beamish and Lowartz 1996). Results of Lee’s (1989) laboratory study supported this 
concept as he found ammocoetes of Petromyzon marinus and Lampetra appendix avoided coarse sand substrate. Further, larvae of the southern brook lamprey also seemed to avoid substrates with a large component of coarse sand (Beamish and Jebbink 1994). The authors speculated that an overabundance of coarse sand could prevent construction of adequate burrows (Beamish and Jebbink 1994).

Substrates with large quantities of organic matter are also sometimes documented as critical habitat for ammocoetes (Leach 1940; Hardisty and Potter 1971; Yap and Bowen 2003). Material found in organic matter, such as detritus, algae, and bacteria, comprise the main component of an ammocoete's diet, so it could represent important habitat (Hardisty and Potter 1971; Yap and Bowen 2003). Leach (1940) found most northern brook lamprey ammocoetes in substrates with large quantities of organic debris. Hardisty and Potter (1971) also noted that optimal ammocoete habitat would have large amounts of organic detritus. In another study, Burr and Shasteen (2007) found the majority of least brook lamprey ammocoetes at sites with 10-20 $\%$ detritus. However, some authors suggest organic matter is not as important as has been suggested (Beamish and Jebbink 1994; Sugiyama and Goto 2002). Sugiyama and Goto (2002) concluded that organic matter was not a significant predictor for ammocoete presence or abundance. Beamish and Jebbink (1994) also concluded that organic content did not significantly affect abundance of southern brook lamprey ammocoetes. Although substances found in organic matter (detritus and algae) make up a significant portion of the diet of ammocoetes, Beamish and Jebbink (1994) concluded that the amount consumed may not be large enough to play a factor in habitat selection.

A few studies have examined differences in substrate selection between different sizes of ammocoetes or have simply mentioned relative field observations. The laboratory and field 
studies of Sugiyama and Goto (2002) revealed significant differences in substrate sizes selected between small and large ammocoetes of the far eastern brook lamprey (Lethenteron reissneri). Larger ammocoetes used substrates of a greater particle size (up to $17 \mathrm{~mm}$ ) than smaller ammocoetes. The larger ammocoetes also did not show a significant selection for any particular substrate size but instead were distributed uniformly among all particle sizes. Small ammocoetes selected substrates with a particle size between $0.125 \mathrm{~mm}$ and $1 \mathrm{~mm}$. The authors suggested that ammocoetes shift habitats between ages 1 and 2, with the small ammocoetes in their study representing age 1 and large ammocoetes representing age 2 and older. Manion and McLean (1971) mention that sea lamprey ammocoetes also exhibit this shift in substrate selection, noting that larger ammocoetes occur in both fine and large particle size substrate. In a field study on ammocoetes of the northern brook lamprey, Leach (1940) assumed segregation in ammocoetes according to body length and substrate size. He reported small ammocoetes from "fine washed sand" and larger ammocoetes from substrates rich in organic debris. Additionally, Seversmith (1953) noted small least brook lamprey ammocoetes in substrates composed of clay/silt, while ammocoetes presumably in their $2^{\text {nd }}$ year or older selected substrates composed mainly of fine sand. For a condensed view of all reviewed studies on ammocoete habitat selection, see Table 1.1.

\section{Habitat Selection and Susceptibility to Predation}

Ecological studies have addressed the relationship between habitat selection behavior and survival in animals (Stein and Magnuson 1976; Sponaugle and Lawton 1990; Wahle and Steneck 1992; Haas et al. 2004). A literature search, however, revealed no published research on the effects of available habitat type or habitat selection behavior of ammocoetes on the susceptibility 
to predation. Most ecological studies, however, have focused on how animals shift their habitat selection when predators are present (Main 1987; Pierce 1988; Jordan et al. 1996; Turner and Montgomery 2003). Another relevant focus area is how the type of habitat available can affect ammocoete susceptibility to predation.

The topic of habitat selection and its effects on the lives of animals has been popular among ecologists. Many studies have shown that habitat selection directly influences an animal’s fitness (Stein and Magnuson 1976; Holomuzki 1986; Main 1987; Pierce 1988; Wahle and Steneck 1992; Jordan et al. 1996; Railsback and Harvey 2002; Railsback et al. 2003; Haas et al. 2004;). It is generally thought that animals should select habitats that facilitate maximum growth (Holomuzki 1986; Railsback and Harvey 2002; Railsback et al. 2003). This should be no different for the primitive ammocoete. After all, it is likely that the faster an ammocoete can attain a large body size, the sooner it can metamorphose and subsequently reproduce. Both net energy intake (growth) and mortality risks can influence habitat selection (Holomuzki 1986; Railsback and Harvey 2002; Railsback et al. 2003). Therefore, ammocoete habitat quality is likely dependent on how well they can feed and breathe, which is possibly dependent on substrate particle size. An animal's perception of habitat quality is also likely related to level of protection from predators. Regardless of substrate type, burrowed ammocoetes are likely well protected from most predators. However, ammocoetes may emerge if feeding and respiration conditions are not adequate (Hardisty and Potter 1971). If so, then substrate sizes associated with suboptimal feeding and respiration conditions could lead to increased ammocoete mortality. This would occur if ammocoetes spent more time emerged searching for better habitat. Therefore, it is possible that habitat type and habitat selection play an important role in predator avoidance in ammocoetes. 
In summary, ammocoetes are thought to avoid substrates with extremely small particle sizes, such as with clay or with excess silt. This is based mainly on the assumption that substrates of these sizes could possibly obstruct the burrows of ammocoetes and therefore suffocate or hinder the ability of ammocoetes to uptake dissolved oxygen and feed (Beamish and Jebbink 1994; Beamish and Lowartz 1996). However, ammocoetes are also thought to avoid large substrates of coarse sand and gravel, possibly owing to the difficulty in burrowing into these substrates and in creating adequate burrows (Beamish and Jebbink 1994; Mundahl 2006). Researchers have also indicated a positive relationship between substrate particle size and ammocoete length (Leach 1940; Seversmith 1953; Potter 1980; Sugiyama and Goto 2002). It is thought that as substrate particle size increases, the length of ammocoetes occupying those substrates also increases (Leach 1940; Seversmith 1953; Potter 1980; Sugiyama and Goto 2002). Finally, it is possible that the habitat selection choices made by ammocoetes may influence their susceptibility to predators. If a substrate provides inadequate burrow stability and feeding opportunities then ammocoetes may subsequently emerge at night to search for more optimal habitat (Hardisty and Potter 1971). If this is the case, then in streams with an overabundance of unsuitable habitat, ammocoetes could suffer inflated mortality rates from predation due to their increased frequency of emergence in search of better habitat.

The following chapters include a laboratory study of substrate selection of ammocoetes of the least brook lamprey and a study investigating the influence of habitat type on predator avoidance in ammocoetes. Results for these studies are conditional based on substrate types available and contribute to our understanding of substrate selection behaviors and the related effects of those behaviors on lamprey ammocoetes. 


\section{Literature Cited}

Beamish, F. W. H., and Austin, L. S. 1985. Growth of the mountain brook lamprey Ichthyomyzon greeleyi Hubbs and Trautman. Copeia, 1985: 881 - 890.

Beamish, F. W. H., and Jebbink, J. 1994. Abundance of lamprey larvae and physical habitat. Env. Biol. Fish. 39: 209 - 214.

Beamish, F. W. H., and Medland, T. E. 1988. Metamorphosis of the mountain brook lamprey Ichthyomyzon greeleyi. Env. Biol. of Fish. 23: 45 - 54.

Beamish, F. W. H., and Lowartz, S. 1996. Larval habitat of American brook lamprey. Can. J. Fish. Aquat. Sci. 53:693 - 700.

Burr, B. M., and Shasteen, D. K. 2007. Distribution, abundance, and habitat requirements of the threatened least brook lamprey, Lampetra aepyptera, in the Shawnee National Forest. Final report to USDA Forest Service, Harrisburg, Illinois.

Dendy, J. S., and Scott, D. C. 1953. Distribution, life history, and morphological variations of the southern brook lamprey, Ichthyomyzon gagei. Copeia, 1953: 152 - 162.

Haas, H. L., Rose, K. A., Fry, B., Minello, T. J., Rozas, L. P. 2004. Brown shrimp on the edge: Linking habitat to survival using an individual based simulation model. Ecol. Appl. 14: $1232-1247$.

Hardisty, M. W., and Potter, I. C. 1971. The biology of lampreys. Vol. 1. Edited by M. W. Hardisty and I. C. Potter. Academic Press, London.

Holomuzki, J. R. 1986. Effect of microhabitat on fitness components of larval tiger salamanders, Ambystoma tigrinum nebulosum. Oecologia, 71: 142 - 148.

Jenkins, R. E., and Burkhead, N. M. 1993. Freshwater fishes of Virginia. American Fisheries Society, Bethesda, Maryland.

Jordan, F., Bartolini, M., Nelson, C., Patterson, P. E., and Soulen, H. L. 1996. Risk of predation affects habitat selection by the pinfish Lagodon rhomboides (Linnaeus). J. of Exp. Mar. Biol. and Ecol. 208: 45 - 56.

Leach, W. J. 1940. Occurrence and life history of the northern brook lamprey, Ichthyomyzon fossor, in Indiana. Copeia, 1940: 21 - 34.

Lee, D. S. 1989. Proximate determinants of larval lamprey habitat selection. Ph.D. thesis, Michigan State University, East Lansing, Mich.

Main, K. L. 1987. Predator avoidance in seagrass meadows: Prey behavior, microhabitat selection, and cryptic coloration. Ecology, 68: 170 - 180. 
Mallatt, J. 1983. Laboratory growth of larval lampreys (Lampetra (Entosphenus) tridentata Richardson) at different food concentrations and animal densities. J. Fish Biol. 22: 293 301.

Malmqvist, B. 1980. Habitat selection of larval brook lampreys (Lampetra planeri, Bloch) in a south Swedish stream. Oecologia, 45: 35 - 38.

Malmqvist, B., and Bronmark, C. 1981. Filter feeding in larval Lampetra planeri: effects of size, temperature, and particle concentration. Oikos, 38: $40-46$.

Manion, P. J., and McLean, A. L. 1971. Biology of larval sea lampreys (Petromyzon marinus) of the 1960 year class, isolated in the Big Garlic River, Michigan, 1960 - 65. Great Lakes Fishery Commission Technical Report. No. 16: 1 - 35.

Moore, J. W., and Potter, I. C. 1976. A laboratory study on the feeding of larvae of the brook lamprey Lampetra planeri (Bloch). J. of Anim. Ecol. 45:81 - 90.

Moyle, P. B., and Cech Jr., J. J. 2004. Fishes an introduction to ichthyology. Pearson Education, Upper Saddle River, New Jersey.

Mundahl, N. D., Sayeed, G., Taubel, S., Erickson, C., Zalatel, A., and Cousins, J. 2006. Densities and habitat of American brook lamprey (Lampetra appendix) larvae in Minnesota. Am. Midl. Nat. 156: 11 - 22.

Nelson, J. S. 2006. Fishes of the World. John Wiley \& Sons, Inc., Hoboken, New Jersey.

Pierce, C. L. 1988. Predator avoidance, microhabitat shift, and risk sensitive foraging in larval dragonflies. Oecologia, 77: $81-90$.

Potter, I. C. 1980. Ecology of larval and metamorphosing lampreys. Can. J. Fish. Aquat. Sci. 37: $1641-1657$.

Purvis, H. A. 1970. Growth, age at metamorphosis, and sex ratio of northern brook lamprey in a tributary of southern Lake Superior. Copeia, 1970: 326 - 332.

Quintella, B. R., Andrade, N. O., Espanhol, R., and Almeida, P. R. 2005. The use of PIT telemetry to study movements of ammocoetes and metamorphosing sea lampreys in river beds. J. of Fish Biol.. 66: 97 - 106.

Reighard, J., and Cummins, H. 1916. Description of a new species of lamprey of the genus Ichthyomyzon. Occ. Pap. Mus. of Zool. Univ. of Mich. 32: 1- 12.

Railsback, S. F., and Harvey, B. C. 2002. Analysis of habitat selection rules using an individual based model. Ecology, 83: 1817 - 1830.

Railsback, S. F., Stauffer, H. B., and Harvey, B. C. 2003. What can habitat preference models tell us? Tests using a virtual trout population. Ecol. Appl. 13: 1580 - 1594.

Renaud, C. B. 1997. Conservation status of northern hemisphere lampreys (Petromyzontidae). J. Appl. Ichthyol. 13: $143-148$. 
Reynolds, W. W., and Casterlin, M. E. 1979. Photokinetic responses and diel activity of sea lamprey Petromyzon marinus ammocoete larvae. J. Fish. Biology. 14: 425 - 428.

Seversmith, H. F. 1953. Distribution, morphology, and life history of Lampetra aepyptera, a brook lamprey, in Maryland. Copeia, 1953: 225 - 232.

Sponaugle, S., and Lawton, P. 1990. Portunid crab predation on juvenile hard clams: effects of substrate type on prey density. Mar. Ecol. Prog. Ser. 67: 43 - 53.

Stein, R. A, and Magnuson, J. J. 1976. Behavioral response of crayfish to a fish predator. Ecology, 57: $751-761$.

Sugiyama, H., and Goto, A. 2002. Habitat selection by larvae of a fluvial lamprey, Lethenteron reissneri, in a small stream and an experimental aquarium. Ichthyol. Res. 49: 62 - 68.

Sutton, T. M., and Bowen, S. H. 1994. Significance of organic detritus in the diet of larval lampreys in the Great Lakes Basin. Can. J. Fish. Aquat. Sci. 51: 2380 - 2387.

Torgensen, C. E., and Close, D. A. 2004. Influence of habitat heterogeneity on the distribution of larval pacific lamprey (Lampetra tridenta) at two spatial scales. Fresh. Biol. 49: 614 -630 .

Turner, A. M., and Montgomery, S. L. 2003. Spatial and temporal scales of predator avoidance: experiments with fish and snails. Ecology, 84: $616-622$.

Wahle, R. A., and Steneck, R. S. 1992. Habitat restrictions in early benthic life: experiments on habitat selection and in situ predation with the American lobster. J. Exp. Mar. Biol. Ecol. 157: $91-114$.

Yap, M.R., and Bowen, S.H. 2003. Feeding by northern brook lamprey (Ichthyomyzon fossor) on sestonic biofilm fragments: habitat selection results in ingestion of a higher quality diet. J. Great Lakes Res. 29: $15-25$. 
Table 1.1. Summary of past research on larval lamprey habitat selection. Substrates listed are those that previous authors have noted or found to be most selected by larval lampreys.

\begin{tabular}{llcrcr}
\multicolumn{1}{c}{ Author } & Year & Species & Substrate & Study Type \\
\hline Reighard and Cummins & 1916 & Ichthyomyzon fossor & Silt/sand & Field Observations \\
Leach & 1940 & Ichthyomyzon fossor & Fine sand/organic sediment & Field Observations \\
Seversmith & 1953 & Lampetra aepyptera & Clay/silt/fine sand & Field Observations \\
Dendy and Scott & 1953 & Ichthyomyzon gagei & Organic sediment & Field Observations \\
Hardisty and Potter & 1971 & Larval lampreys in general & Clay/silt/organic sediment & Field Observations \\
Potter & 1980 & Mordacia mordax & Clay/silt & Field Observations \\
Lee & 1989 & Petromyzon marinus & Medium/fine sand & Lab Experiment \\
Lee & 1989 & Lampetra appendix & Medium/fine sand & Lab Experiment \\
Beamish and Jebbink & 1994 & Ichthyomyzon gagei & Medium/fine sand & Field Study \\
$\begin{array}{l}\text { Beamish and Lowartz } \\
\text { Sugiyama and Goto }\end{array}$ & 1996 & Lampetra appendix & Medium/fine sand & Field Study \\
Yap and Bowen & 2002 & Lethenteron reissneri & Fine sand/silt & Lab Experiment \\
Mundahl et al. & 2003 & Ichthyomyzon fossor & Organic sediment & Field Study \\
Burr and Shasteen & 2006 & Lampetra appendix & Medium/fine sand & Field Study \\
\hline
\end{tabular}




\title{
Selection and Preference of Benthic Habitat by Larval Lampreys
}

\begin{abstract}
Larval lampreys (ammocoetes) create burrows in the soft, benthic substrate of streams, which serve as refuge and foraging habitat. Because of the importance of benthic substrates, population declines of some lamprey species has been attributed to the alteration of stream habitat. Many descriptions of ammocoete habitat, however, have been reported as secondary observations, and few experimental studies have quantified habitat use, such as selection of benthic substrate sizes. In this laboratory study, we quantified substrate selection by small $(<50$ $\mathrm{mm}$ ) and large (100 - $150 \mathrm{~mm}$ ) ammocoetes of the least brook lamprey (Lampetra aepyptera). In aquaria, ammocoetes were given a choice to burrow into six equally-available substrate types: small gravel (2.36-4.75 mm), coarse sand $(0.5-1.4 \mathrm{~mm})$, fine sand $(0.125-0.5 \mathrm{~mm})$, organic debris (approximately 70\% decomposing leaves and stems, 15\% silt, and 15\% sand), an even mixture of silt, clay, and fine sand, and silt/clay $(<0.063 \mathrm{~mm})$. Fine sand was selected with a significantly higher probability than any other substrate. Fine sand habitat is limited in many streams, in part owing to geology, but also as a result of excessive clay and silt sedimentation - a conservation concern. Our results indicate that ammocoetes of least brook lampreys are habitat specialists that prefer fine sand habitat. Hence, availability of fine sand habitat may limit distributions and population sizes.
\end{abstract}

\section{Introduction}

Other than the sea lamprey (Petromyzon marinus) little research exists on the habitat requirements of lampreys despite worldwide declines of many species. Some researchers have suggested habitat degradation as a possible cause for declines of lamprey populations (Renaud 1997; Close et al. 2002). Degradation of benthic habitat in streams is likely associated with population declines because larval lampreys (ammocoetes) burrow in benthic habitats (Potter and Bailey 1972; Beamish 1982; Beamish and Thomas 1984; Beamish and Medland 1988). Adult lampreys construct nests and deposit eggs within high velocity areas of streams (Jenkins and Burkhead 1993; Moyle and Cech Jr. 2004; Jang and Lucas 2005). Newly hatched ammocoetes 
are eventually swept downstream and burrow into bottom substrate in low velocity areas (Hardisty and Potter 1971; Jenkins and Burkhead 1993). As ammocoetes, lampreys require soft substrate to burrow into and live out the larval stage (Applegate 1950; Hardisty and Potter 1971); but benthic habitats of streams often contain several types of soft substrate, such as clay, silt, and sand. Selection and preference of specific types of soft substrate by ammocoetes are poorly understood, and further studies would be useful for management and conservation of lamprey species in decline.

When an ammocoete burrows, mucous secreted from the endostyle solidifies sediment particles of burrow walls (Sterba 1962, as cited in Hardisty and Potter 1971; Jenkins and Burkhead 1993; Beamish and Lowartz 1996). Ammocoetes spend the majority of their lifetime within burrows, pumping in water for respiration and filtering food (Hardisty and Potter 1971; Malmqvist and Bronmark 1981; Mallatt 1983; Sutton and Bowen 1994). A stable burrow facilitates successful breathing and feeding by allowing adequate flow of water to the ammocoete (Hardisty and Potter 1971; Beamish and Jebbink 1994; Beamish and Lowartz 1996).

Several researchers have examined habitat of ammocoetes, and most emphasize the importance of suitable bottom substrate (Hardisty and Potter 1971; Potter 1980; Beamish and Jebbink 1994; Beamish and Lowartz 1996). Most studies conclude that soft sediment is important, as well as organic matter (Hardisty and Potter 1971; Potter 1980). Some authors cite clay as important, others specify silt, and still others have emphasized the importance of sand (Hardisty and Potter 1971; Potter 1980; Beamish and Jebbink 1994; Beamish and Lowartz 1996; Mundahl et al. 2006). The uncertainty of specific habitat use of ammocoetes may result, in part, from observational studies with small sample sizes. Beamish and Lowartz (1996) identify this problem by noting that most studies have examined habitat in only one stream. Most field 
studies do not really measure habitat preference because ammocoetes do not have a choice of selecting from equally available habitat types. Given the limited scope and lack of control in previous studies, there is an obvious need for experimental studies that allow for stronger inference about selection of habitat by ammocoetes.

Little published research exists on substrate selection behavior by least brook lamprey (Lampetra aepyptera). This is troublesome in that the least brook lamprey is one of the most common species of lamprey in the Appalachian region of the United States, yet is a species in decline. It is also unclear as to whether different size classes of ammocoetes select different substrate types. Some researchers reported that smaller ammocoetes select finer substrates than larger ammocoetes (Leach 1940; Seversmith 1953; Manion and McLean 1971; Beamish and Jebbink 1994; Sugiyama and Goto 2002).

The objective of this aquaria-based experimental study was to examine habitat preference and selection for or against habitat types by the least brook lamprey. A secondary objective of this study was to assess differences in the substrate selection by small and large ammocoetes.

\section{Methods}

\section{Ammocoete Collection}

We collected ammocoetes of Lampetra aepyptera with a backpack electrofisher (SmithRoot, Inc.) in September and October 2007. Ammocoetes were separated into two size classes for experimental use: small $(<50 \mathrm{~mm})$ and large $(100-150 \mathrm{~mm})$. In the laboratory, ammocoetes were held in two 379-L (100-gal) holding tanks through December 2007, and 
separated into metamorphosing ammocoetes and non-metamorphosing ammocoetes in January 2008 (Cochran 1989). Only non-metamorphosing ammocoetes were used for this study. All ammocoetes were fed Brewer's yeast throughout the study, as suggested by Murdoch et al. (1991).

Aquaria Setup

Six 246-L (65-gal) glass aquaria $(91.5 \mathrm{~cm}$ x $45.8 \mathrm{~cm}$ x $53 \mathrm{~cm})$ were used for the substrate selection study. A sequence pump ( $2.6 \mathrm{~L} / \mathrm{min})$ recirculated water from a 379-L sump to the aquaria. Water quality was maintained with carbon filters, bio balls, and fresh water substitutions. Water temperature varied from $15.1-16.7^{\circ} \mathrm{C}$ throughout the study. Photoperiod was maintained with wide spectrum fluorescent plant bulbs and an electric timer (12 hr light, 12 hr dark). Three of these aquaria were used for small ammocoetes and three for large ammocoetes. Within each aquarium, six plastic substrate containers $(15 \mathrm{~cm}$ x $28 \mathrm{~cm}$ x $15 \mathrm{~cm})$ were filled with different types of substrate to $10 \mathrm{~cm}$ depth. Substrate was collected from study streams and separated into size classes with U.S. standard test sieves \#'s 4, 8, 14, 35, 120, and 230. The six substrate types were gravel (2.36-4.75 mm), coarse sand $(0.5-1.4 \mathrm{~mm})$, fine sand (0.125-0.5 mm), silt/clay $(<0.063 \mathrm{~mm})$, an even mixture of silt, clay, and fine sand, and lastly, organic debris (approximately 70\% decomposing leaves and stems, 15\% silt, and 15\% sand). Clay and silt particles could not be partitioned by size, but were separated by texture using USDA soil descriptions methods (USDA 2001). 


\section{Experimental Design}

An aquaria-based study examined substrate selection in the two size classes of Lampetra aepyptera ammocoetes. Ten trials were conducted from 19 Feb to 29 Apr 2008. For each trial in the small and large ammocoete studies, 10 individuals were released into each aquarium and given a choice of six different substrate types of equal availability. By offering ammocoetes a choice of six randomly-placed substrate types in equal proportions, we were able to examine habitat selection and preference (Garshelis, D. L. 2000; Alldredge and Griswold 2006). Seven days after releasing the ammocoetes, the substrate containers were removed from each aquarium, and the total number of ammocoetes was counted within each substrate type.

\section{Statistical Analysis}

For this study, the log likelihood ratio test (G-test, Manly et al. 2002) was used to address an initial question: Do ammocoetes select substrate at random and in proportion to availability? We also wanted to know whether certain substrates were selected more or less than other substrates. For this we calculated selection ratios for each substrate type and then subsequently calculated Bonferroni confidence intervals for each (Manly et al. 2002). The selection ratio for a given substrate type is the ratio of the proportion used to the proportion of availability (Manly et al. 2002). A selection ratio close to 1 indicates no selectivity for a given habitat type. Large selection ratios support selection for a habitat type, whereas small ratios indicate selection against a habitat type (i.e., avoidance; Manly et al. 2002). Bonferroni confidence intervals (95 \%) assessed statistical significance of selection ratios, where intervals of selection ratios or odds ratios are considered significant if they do not contain the value of 1 (Manly et al. 2002). 
Additionally, we conducted pairwise comparisons between selection ratios using Bonferroni confidence intervals (Manly et al. 2002). For statistical analysis, data for gravel and silt/clay were pooled because of the low occurrence of ammocoetes in these substrate types. Without pooling, data would not have met the minimum expected cell count of 6 for the chi-squared distribution (Manly et al. 2002).

We used a Pearson chi-squared test to determine if small and large ammocoetes differed significantly in selection of at least one substrate type. Given a significant result from the Pearson chi-squared test, we then calculated odds ratios from a multinomial logit model to examine differences in substrate selection between small and large ammocoetes (Hosmer and Lemeshow 2000). Odds ratios were estimated for each habitat type, but one habitat category was required as a "reference category," and we designated the fine sand habitat for reference. In our case, an odds ratio of 2.0 for one habitat category indicates that large ammocoetes are 2 times more likely than small ammocoetes to select that category over the reference category of fine sand (Hosmer and Lemeshow 2000). For instance, if the chances of a large ammocoete selecting a certain substrate over fine sand were 1 to 25 (i.e., 0.04) and the chances of a small ammocoete selecting a certain substrate over fine sand were 1 to 50 (i.e., 0.02) then this translates to large ammocoetes being 2 times more likely to select that substrate over fine sand than small ammocoetes (i.e.. 0.04/0.02 = 2), even though the chances of an ammocoete selecting a substrate other than fine sand are small. We then calculated Wald confidence intervals for odds ratios to test for differences between substrate types of small and large ammocoetes, where intervals were significant when not containing the value 1 (Hosmer and Lemeshow 2000). 


\section{Results}

Small Ammocoete Habitat Selection

Small ammocoetes did not select substrate at random or in proportion to availability (Gtest; $\mathrm{p}<0.001)$. Of six available habitat types, fine sand was selected by 164 of 300 (54.7\%) small ammocoetes (Figure 2.1). Organic debris was selected by 92 (30.7\%) small ammocoetes (Figure 2.1). With $84.5 \%$ selecting either fine sand or organic debris, the remaining habitat types of coarse sand ( $n=27)$, gravel (9), silt/clay/sand mixture (8), and silt/clay (0) were rarely chosen by small ammocoetes (Table 2.1). This pattern of habitat selection can also be visualized by plotting median number of small ammocoetes in each habitat type for the 10 trials, where median values were highest for fine sand followed by organic debris (Figure 2.2). Selection ratios of habitat types and their associated $95 \%$ Bonferroni confidence intervals indicated significant selection for fine sand and organic debris and significant selection against coarse sand, silt/clay/sand mixture, and the pooled gravel and silt/clay category (Table 2.2). Pairwise comparisons revealed that fine sand was selected with significantly higher probability than any other substrate, including organic debris (Table 2.3). In contrast, the pooled gravel and silt/clay category and the silt/clay/sand mixture were avoided with significantly higher probability than any other substrate.

\section{Large Ammocoete Habitat Selection}

For large ammocoetes, the six substrate types were not selected at random or in proportion to availability (G-test; $\mathrm{p}<0.001$ ). Of a total of 300 large ammocoetes, the number and percentage of highest habitat usage were fine sand (149, 49.7\%), organic debris (76, 25.3\%), 
and coarse sand (53, 17.7\%) (Table 2.1; Figure 2.1). Few individuals used the remaining habitat types of gravel $(\mathrm{n}=0)$, silt/clay/sand mixture (19), and silt/clay (3) (Table 2.1). This pattern of differential selection among habitat types is also supported by the median number of individuals in each habitat type for the 10 trials, where median values were highest for fine sand followed by organic debris (Figure 2.3). Selection ratios of habitat types and their associated 95 \% Bonferroni confidence intervals indicated significant selection for fine sand and organic debris and significant selection against the silt/clay/sand mixture and the pooled gravel and silt/clay category (Table 2.2). The selection ratio of coarse sand (1.06) was close to 1.0, indicating no selectivity of large ammocoetes for this habitat type. Pairwise comparisons revealed that fine sand was selected with significantly higher probability than any other substrate category, including organic debris (Table 2.3). Organic debris was selected with significantly higher probability than gravel, silt/clay, and the silt/clay/sand mixture but was not significant from coarse sand. In contrast, the pooled gravel and silt/clay category was avoided with significantly higher probability than any other substrate. Pairwise comparisons of coarse sand versus organic debris and coarse sand versus silt/clay/sand mixture were not significant.

\section{Small versus Large Ammocoete Habitat Selection}

The Pearson chi-squared test indicated that small and large ammocoetes differed significantly ( $\mathrm{n} \cong 0.0008$ ) in selection of at least one habitat type. The odds ratios and Wald confidence intervals indicated a significant effect of ammocoete size on selection for coarse sand and silt/clay/sand mixture (Table 2.4). Because coarse sand and silt/clay/sand mixture were not significantly selected by either small or large ammocoetes, the importance of this difference in 
habitat selection between size classes is questionable. However, almost twice the number of large ammocoetes (53 of 300) selected coarse sand when compared to the same ratio of small ammocoetes (27 of 300).

\section{Discussion}

In this study, small and large ammocoetes of the least brook lamprey were habitat specialists based on their primary preference for fine sand and their secondary preference for habitat with 70\% organic debris. Our findings are conditional on six habitat types, but these types were selected based on the range of habitats expected from relatively undisturbed to severely impacted streams. However, habitat selection in the field may be somewhat more complicated than is represented through this study. Although we chose substrates representing a range of stream conditions, other factors such as the slope of the stream bottom and water current may also influence habitat selection (P. Cochran, St. Mary’s University of Minnesota, personal communication). Nevertheless, based on the six substrate types used for this study, small and large ammocoetes selected substrate nonrandomly and disproportionately to availability. Although our study provided habitat types in equal availability (a necessary design to document preference), the availability of fine sand and organic habitat in streams is influenced, in part, by land use within the watershed. Land development and alteration, reduction of riparian zones, and other causes of stream sedimentation may have important effects on least brook lamprey populations. In our study, small and large lampreys selected against habitat types with high clay or silt content, and these habitat types are increased to unnatural levels by human-induced stream 
sedimentation. Channelization is another influence that can reduce fine sand habitat via reduction in stream sinuosity conducive to formation of fine sand beds.

Benthic habitat in streams is essential for lamprey ammocoetes, given that much of their lives are spent burrowed in the bottom substrate (Seversmith 1953; Hardisty and Potter 1971; Potter and Bailey 1972; Potter 1980; Beamish 1982; Jenkins and Burkhead 1993). Not only do they require adequate substrate to feed and breathe properly, but substrate also serves as a refuge from predators (Hardisty and Potter 1971; Potter 1980; Renaud 1997; Close et al. 2002; Kearn 2004). Several studies have identified the importance of specific substrate particle sizes in allowing ammocoetes to construct stable, yet unobstructed burrows (Beamish and Jebbink 1994; Beamish and Lowartz 1996). Small particles, such as clay, have the propensity to compact, which can have several negative consequences for ammocoetes (Beamish and Jebbink 1994; Beamish and Lowartz 1996). Initially, ammocoetes could have difficulty burrowing into compact clay (Beamish and Lowartz 1996). If ammocoetes manage to burrow into clay, their burrow openings could become compacted with reduced or complete loss of water flow for respiration and feeding. Also, an excess of small particles such as clay and silt could inhibit oxygen uptake by ammocoetes (Beamish and Jebbink 1994; Beamish and Lowartz 1996).

Several studies have identified clay and silt as being unsuitable ammocoete habitat (Reighard and Cummins 1916; Beamish and Jebbink 1994; Beamish and Lowartz 1996; Mundahl et. al 2006). Alternatively, other studies have reported clay and silt as important ammocoete habitat. Hardisty and Potter (1971) proposed that clay and silt were essential for high quality ammocoete habitat. They suggested that substrates with a large clay fraction had an "open structured sediment" thus allowing for more adequate burrows. Potter (1980) determined that larvae of Mordacia mordax were more common in sites where clay and silt comprised $25 \%$ 
of the substrate versus a site where clay and silt only composed $1 \%$. Possibly, some interspecific differences exist in habitat requirements; hence, our findings of habitat use in least brook lamprey may differ from those of studies of other species. Also, many conclusions concerning habitat use in ammocoetes are based on observational studies with small sample sizes. Inference from our experimental study indicates that clay and silt are not preferred habitat for ammocoetes of least brook lamprey, and these habitats were avoided when they were given a choice of alternative habitat types.

Bottom substrates must be composed of particle sizes that allow for both stable burrows and good water circulation for respiration and feeding. Fine sand is probably ideal for burrowing and burrow construction (Beamish and Jebbink 1994; Beamish and Lowartz 1996), and was the preferred substrate in our study for small and large ammocoetes of least brook lamprey. Fine sand also probably allows for optimum flow of water and thus optimum feeding and breathing (Beamish and Jebbink 1994; Beamish and Lowartz 1996). Some studies have reported fine sand or medium fine sand as optimal ammocoete habitat (Seversmith 1953; Potter et al. 1986; Lee 1989; Beamish and Jebbink 1994; Beamish and Lowartz 1996; Jellyman and Glova 2002; Sugiyama and Goto 2002; Mundahl et al. 2006; Burr and Shasteen 2007). It is also one of the few substrates that has not been reported as being avoided or as being an insignificant predictor of ammocoete presence or abundance.

Our study also documented selection against benthic substrate with larger particle sizes. We found selection against gravel by large and small ammocoetes. Coarse sand was significantly selected against by small ammocoetes, but was neither selected for or against by large ammocoetes. Large particles such as very coarse sand and small gravel could be too heavy for ammocoetes to move, thus making it difficult to penetrate (Beamish and Jebbink 1994; 
Beamish and Lowartz 1996). If ammocoetes do burrow into a substrate of large particles, their burrows may be prone to collapsing. Mucous secretions used to hold burrows together may not be adequate for binding larger particles (Beamish and Jebbink 1994; Beamish and Lowartz 1996). Burrow collapse would lead to decreased respiration and feeding efficiency. Several other studies have identified large particles such as coarse sand and gravel as being inappropriate for ammocoetes (Manion and McLean 1971; Lee 1989; Beamish and Jebbink 1994; Sugiyama and Goto 2002; Mundahl et. al 2006). In our study, coarse sand habitat was used by a moderate number of large ammocoetes and may serve as an alternative habitat if fine sand and organic debris are unavailable.

The association of ammocoetes and organic debris is possibly linked to foraging. Ammocoetes filter feed on items such as detritus, bacteria, and algae. The importance of organic matter in habitat selection by ammocoetes has been debated. Many researchers believe that organic matter, an important component of an ammocoete’s diet, has a significant effect on habitat selection in ammocoetes. Several studies have identified organic matter as a significant predictor of ammocoete presence or abundance (Leach 1940; Hardisty 1944; Dendy and Scott 1953; Hardisty and Potter 1971; Potter et. al 1986; Beamish and Lowartz 1996; Yap and Bowen 2003; Burr and Shasteen 2007). Other studies have found no evidence for organic matter as a predictor of ammocoete presence or abundance (Malmqvist 1980; Beamish and Jebbink 1994; Sugiyama and Goto 2002). In our study, organic debris likely stored the greatest quantity of food for ammocoetes, but it was not selected as often as fine sand. Beamish and Jebbink (1994) suggested that ammocoetes consume such a small amount of food items associated with organic debris that it may have little impact on their habitat selection. Therefore, it is entirely possible that enough organic material was in the water column for ammocoetes to select the more suitable 
substrate of fine sand and still obtain adequate amounts of food. Also, the organic debris substrate was mixed with approximately $15 \%$ sand and $15 \%$ silt, and we are uncertain if this influenced ammocoete selection of this habitat. Organic debris is often distributed as a layer on top of other stream substrates, so additional habitat selection experiments should examine substrate types overlain by a layer of organic debris.

Ammocoetes that burrow in unsuitable habitat may emerge at night in search of optimal substrates (Hardisty and Potter 1971; Reynolds and Casterlin 1979; Potter 1980; Torgensen and Close 2004; Quintella et al. 2005). Some general observations during our experimental study support this behavior, as ammocoetes released into aquaria attempted to burrow into the first substrate randomly encountered and subsequently many ammocoetes switched habitat between the time of initial burrowing and the end of trials. A pilot study was conducted previous to this experiment to identify any density related effects on habitat selection. The pilot study indicated that as many as 20 large ammocoetes would burrow into a substrate container filled with fine sand and not switch habitats. Therefore, given the low sample size per aquaria for each trial $(\mathrm{n}=10)$, we do not believe that habitat switching was associated with achieving an ideal free distribution (Fretwell and Lucas 1969). In addition, during stream sampling for ammocoetes, individuals were often observed within fine sand habitat in slow velocity areas of streams. Thus, it is probable that if ammocoetes burrowed randomly into a substrate other than fine sand initially, they may have emerged from that substrate because of an inability to sufficiently feed and respire.

Although small and large ammocoetes did not differ significantly in their use of organic debris, large ammocoetes used coarse sand habitat (53 of 300) and clay/silt/sand mixture (19 of 300 ) at nearly twice the rate than that of small ammocoetes (27 of 300 and 8 of 300, 
respectively). Our data indicate that small ammocoetes are narrower habitat specialists given their higher percentages of use for fine sand and organic debris, and their low use of coarse sand, clay/silt/sand mixture, and silty clay. A few studies have commented on differences in habitat selection by different sizes of ammocoetes. In the study by Sugiyama and Goto (2002) small (< $50 \mathrm{~mm}$ ) ammocoetes of Lethenteron reissneri selected fine sand substrates, whereas large (100 $150 \mathrm{~mm}$ ) ammocoetes did not significantly select a certain substrate, but were instead uniformly distributed throughout habitats of different particle sizes. Manion and McLean (1971) noted an ontogenetic shift in habitat use by ammocoetes of Petromyzon marinus, by which sand/silt habitat was used for the first 2 years of life before a change to larger substrates with a greater proportion of detritus. Leach (1940) observed that ammocoetes of Ichthyomyzon fossor appeared to be segregated according to body length and substrate size, with smaller ammocoetes occurring in fine sand and larger ammocoetes occurring in larger substrates rich in organic debris. Finally, Seversmith (1953) noted an ontogenetic habitat shift by Lampetra aepyptera ammocoetes, by which first and second year ammocoetes used fine sand and third year ammocoetes shifted to coarser sand. He also noted that in late winter and early spring, older ammocoetes occupied substrates with large amounts of organic material.

In conclusion, our study demonstrates a habitat preference for fine sand by small and large ammocoetes of the least brook lamprey, and these findings have conservation implications. In recent years, lamprey populations have declined possibly due to habitat degradation (Jenkins and Burkhead 1993; Renaud 1997; Close et al. 2002; Moyle and Cech Jr. 2004). Lampreys go through distinct life phases with different habitat needs (Jenkins and Burkhead 1993; Renaud 1997; Kearn 2004; Moyle and Cech Jr. 2004). Adult least brook lampreys require streams with clean gravel riffles for successful spawning, but larval lampreys have completely different 
habitat needs due to their burrowing lifestyle (Hardisty and Potter 1971; Jenkins and Burkhead 1993; Renaud 1997). If we wish to conserve populations of least brook lamprey, steps should be taken to preserve existing fine sand habitat in streams supporting lamprey populations. To do this, effects from certain anthropogenic activities that degrade and reduce fine sand habitat must be minimized, such as sedimentation and channelization. Stream sedimentation leads to artificially high amounts of clay and silt particles, which then can blanket and reduce the amount of high quality fine sand habitat (Jenkins and Burkhead 1993; Kohler and Hubert 1999). Stream channelization reduces the number of natural meanders, which are critical for the creation of fine sand beds (Jenkins and Burkhead 1993; Kohler and Hubert 1999; Close et al. 2002). By reducing the occurrence and magnitude of sedimentation and channelization, we can help preserve fine sand habitat, which may be critical for the persistence of least brook lamprey populations.

\section{Literature Cited}

Alldredge, J. R., and Griswold, J. 2006. Design and analysis of resource selection studies for categorical resource variables. J. of Wild. Mgmt. 70: 337 - 346.

Applegate, V. C. 1950. Natural history of the sea lamprey (Petromyzon marinus) in Michigan. Spec. Sci. Rep. Wildl. U.S. Fish Wildl. Serv. No. 55. pp. 1 - 237.

Beamish, W. H. 1982. Biology of the southern brook lamprey, Ichthyomyzon gagei. Env. Biol. Fish. 7: $305-320$.

Beamish, F. W. H., and Jebbink, J. 1994. Abundance of lamprey larvae and physical habitat. Env. Biol. Fish. 39: 209 - 214.

Beamish, F. W. H., and Medland, T. E. 1988. Metamorphosis of the mountain brook lamprey Ichthyomyzon greeleyi. Env. Biol. Fish. 23: 45 - 54.

Beamish, F. W. H., and Lowartz, S. 1996. Larval habitat of American brook lamprey. Can. J. Fish. Aquat. Sci. 53:693 - 700. 
Beamish, F. W. H., and Thomas, E. J. 1984. Metamorphosis of the southern brook lamprey, Ichthyomyzon gagei. Copeia, 1984: 502 - 515.

Burr, B. M., and Shasteen, D. K. 2007. Distribution, abundance, and habitat requirements of the threatened least brook lamprey, Lampetra aepyptera, in the Shawnee National Forest. Final report to USDA Forest Service, Harrisburg, Illinois.

Close, D. A., Fitzpatrick, M. S., and Li, H. W. 2002. The ecological and cultural importance of a species at risk of extinction, pacific lamprey. Fisheries, 27: $19-25$.

Cochran, P. A. 1989. Maintaining parasitic lampreys in closed laboratory systems. Am. Biol. Teach. 51: $115-119$.

Dendy, J. S., and Scott, D. C. 1953. Distribution, life history, and morphological variations of the southern brook lamprey, Ichthyomyzon gagei. Copeia, 1953: 152 - 162.

Fretwell, S. D., and Lucas, H. L. 1969. On territorial behavior and other factors influencing habitat distribution in birds. Acta Biotheoretica, 19: $16-36$.

Garshelis, D. L. 2000. Delusions in habitat evaluation: measuring use, selection, and importance. In Research techniques in animal ecology: controversies and consequences. Edited by L. Boitani, and T. K. Fuller. Columbia University Press, New York, USA. pp. 111-164.

Hardisy, M. W. 1944. The life history and growth of the brook lamprey (Lampetra planeri). The J. of Anim. Ecol. 13: 110 - 122.

Hardisty, M. W., and Potter, I. C. 1971. The biology of lampreys. Vol. 1. Academic Press, London.

Hosmer, D. W., and Lemeshow, S. 2000. Applied logistic regression. John Wiley \& Sons, Inc., Hoboken, New Jersey.

Jang, M. H., and Lucas, M. C. 2005. Reproductive ecology of the river lamprey. J. of Fish Biol. 66: $499-512$.

Jellyman, D. J., and Glova, G. J. 2002. Habitat use by juvenile lampreys (Geotria australis) in a large New Zealand river. N. Zeal. J. of Mar. Fresh. Res. 36: 503 - 510.

Jenkins, R. E., and Burkhead, N. M. 1993. Freshwater fishes of Virginia. American Fisheries Society, Bethesda, Maryland.

Kearn, G. C. 2004. Leeches, lice, and lampreys. Springer, Dordrecht, The Netherlands.

Kohler, C. C., and Hubert, W. A., editors. 1999. Inland fisheries management in North America, $2^{\text {nd }}$ edition. American Fisheries Society, Bethesda, Maryland.

Leach, W. J. 1940. Occurrence and life history of the northern brook lamprey, Ichthyomyzon fossor, in Indiana. Copeia, 1940: $21-34$. 
Lee, D. S. 1989. Proximate determinants of larval lamprey habitat selection. Ph.D. thesis, Michigan State University, East Lansing, Mich.

Mallatt, J. 1983. Laboratory growth of larval lampreys (Lampetra (Entosphenus) tridentata Richardson) at different food concentrations and animal densities. J. Fish Biol. 22: 293 301.

Malmqvist, B. 1980. Habitat selection of larval brook lampreys (Lampetra planeri, Bloch) in a south Swedish stream. Oecologia, 45: 35 - 38.

Malmqvist, B., and Bronmark, C. 1981. Filter feeding in larval Lampetra planeri: effects of size, temperature, and particle concentration. Oikos, 38: 40 - 46.

Manion, P. J., and McLean, A. L. 1971. Biology of larval sea lampreys (Petromyzon marinus) of the 1960 year class, isolated in the Big Garlic River, Michigan, 1960 - 65. G. Lakes Fish. Comm. Tech. Rep. No. 16: $1-35$.

Manly, B. F. J., McDonald, L. L, Thomas, D. L., McDonald, T. L., and Erickson, W. P. 2002. Resource selection by animals. Kluwer Academic Publishers , Dordrecht, The Netherlands.

Moyle, P. B., and Cech Jr., J. J. 2004. Fishes an introduction to ichthyology. Pearson Education, Upper Saddle River, New Jersey.

Mundahl, N. D., Sayeed, G., Taubel, S., Erickson, C., Zalatel, A., and Cousins, J. 2006. Densities and habitat of American brook lamprey (Lampetra appendix) larvae in Minnesota. Am. Midl. Nat. 156: 11 - 22.

Murdoch, S. P., Beamish, F. W. H., and Docker, M. F. 1991. Laboratory study of growth and interspecific competition in larval lampreys. Trans. Am. Fish. Soc. 120: 653 - 656.

Potter, I. C. 1980. Ecology of larval and metamorphosing lampreys. Can. J. Fish. Aquat. Sci. 37: $1641-1657$.

Potter, I. C., and Bailey, J. R. 1972. The life cycle of the Tennessee brook lamprey, Ichthyomyzon hubbsi Raney. Copeia, 1972: 470 - 476.

Potter, I. C., Hilliard, R. W., Bradley, J. S., and McKay, R. J. 1986. The influence of environmental variables on the density of larval lampreys in different seasons. Oecologia, 70: $433-440$.

Quintella, B. R., Andrade, N. O., Espanhol, R., and Almeida, P. R. 2005. The use of PIT telemetry to study movements of ammocoetes and metamorphosing sea lampreys in river beds. J. of Fish Biol.. 66: 97 - 106.

Reighard, J., and Cummins, H. 1916. Description of a new species of lamprey of the genus Ichthyomyzon. Occ. Pap. Mus. Zool. Univ. of Mich. 32: 1 - 12.

Renaud, C. B. 1997. Conservation status of northern hemisphere lampreys (Petromyzontidae). J. Appl. Ichthyol. 13: $143-148$. 
Reynolds, W. W., and Casterlin, M. E. 1979. Photokinetic responses and diel activity of sea lamprey Petromyzon marinus ammocoete larvae. J. Fish. Biol. 14: 425 - 428.

Seversmith, H. F. 1953. Distribution, morphology, and life history of Lampetra aepyptera, a brook lamprey, in Maryland. Copeia, 1953: 225 - 232.

Sterba, G. 1962. Die Neunaugen (Petromyzontidae). In Handbuch der Binnenfischerei Mitteleuropas. Vol. 3. Edited by R. Demoll and H. N. Maier. E. Schweizerbart'sche, Verlagsbuchhandlung, Stuttgart, Germany. pp. 263 -352.

Sugiyama, H., and Goto, A. 2002. Habitat selection by larvae of a fluvial lamprey, Lethenteron reissneri, in a small stream and an experimental aquarium. Icthyol. Res. 49: 62 - 68.

Sutton, T. M., and Bowen, S. H. 1994. Significance of organic detritus in the diet of larval lampreys in the Great Lakes Basin. Can. J. Fish. Aquat. Sci. 51: 2380 - 2387.

Torgensen, C. E., and Close, D. A. 2004. Influence of habitat heterogeneity on the distribution of larval pacific lamprey (Lampetra tridentata) at two spatial scales. Fresh. Biol. 49: $614-630$.

Yap, M.R., and Bowen, S.H. 2003. Feeding by northern brook lamprey (Ichthyomyzon fossor) on sestonic biofilm fragments: habitat selection results in ingestion of a higher quality diet. J. Great Lakes Res. 29: 15 - 25.

U.S. Department of Agriculture. 2001. Soil survey manual, $3^{\text {rd }}$ Chapter. University of the Pacific Press, Honolulu, Hawaii. 
Table 2.1. Total number and percentage of small and large ammocoetes selecting each habitat

\begin{tabular}{lcccc} 
& \multicolumn{2}{c}{ Small ammocoetes } & \multicolumn{2}{c}{ Large ammocoetes } \\
\hline Habitat & \# of Ammocoetes & \% of Ammocoetes & \# of Ammocoetes & \% of Ammocoetes \\
\hline Silt/clay & 0 & 0.0 & 3 & 1.0 \\
SCS mix & 8 & 2.7 & 19 & 6.3 \\
Fine sand & 164 & 54.7 & 149 & 49.7 \\
Coarse sand & 27 & 9.0 & 53 & 17.7 \\
Gravel & 9 & 3.0 & 0 & 0.0 \\
Organic debris & 92 & 30.7 & 76 & 25.3 \\
\hline
\end{tabular}

Table 2.2. Habitat selection ratios $+/-95 \% \mathrm{Cl}$ for small and large ammocoetes

Small ammocoetes

Large ammocoetes

\begin{tabular}{lccccccccc}
\hline & \multicolumn{1}{c}{$\begin{array}{c}\text { Selection } \\
\text { Ratios }\end{array}$} & Lower Cl & Upper Cl & & Selection \\
Ratios & Lower Cl & Upper Cl \\
\hline Gravel+silt/clay & 0.09 & 0.008 & 0.172 & $*$ & 0.03 & 0 & 0.074 & $*$ \\
SCS mix & 0.16 & 0.034 & 0.286 & $*$ & 0.38 & 0.12 & 0.64 & $*$ \\
Fine sand & 3.28 & 2.747 & 3.813 & $* *$ & 2.98 & 2.661 & 3.299 & $* *$ \\
Coarse sand & 0.54 & 0.308 & 0.772 & $*$ & 1.06 & 0.545 & 1.575 & ns \\
Organic debris & 1.84 & 1.299 & 2.381 & $* *$ & 1.52 & 1.064 & 1.976 & $* *$ \\
\hline
\end{tabular}

* Significant selection against habitat. ${ }^{* *}$ Significant selection for habitat. ns not significant 
Table 2.3. Pairwise comparisons with Bonferroni $95 \% \mathrm{Cls}$ of habitat selection for small and large ammocoetes.

\begin{tabular}{lcccccc} 
Habitat comparison & Lower Cl & Upper Cl & & Lower Cl & Upper Cl & \\
\hline Coarse sand vs. fine sand & -3.465 & -2.015 & $*$ & -2.66 & -1.18 & $*$ \\
Gravel+silt/clay vs. fine sand & -3.779 & -2.601 & $*$ & -3.315 & -2.585 & $*$ \\
SCS mix vs. fine sand & -3.676 & -2.564 & $*$ & -3.043 & -2.157 & $*$ \\
Organic debris vs. fine sand & -2.572 & -0.308 & $*$ & -2.16 & -0.76 & $*$ \\
Coarse sand vs. organic debris & -1.928 & -0.672 & $*$ & -1.414 & 0.494 & $n s$ \\
Gravel+silt/clay vs. organic debris & -2.375 & -1.125 & $*$ & -1.981 & -0.999 & $*$ \\
SCS mix vs. organic debris & -2.329 & -1.031 & $*$ & -1.744 & -0.536 & $*$ \\
Coarse sand vs. SCS mix & 0.041 & 0.719 & $*$ & -0.055 & 1.415 & $\mathrm{~ns}$ \\
Gravel+silt/clay vs. SCS mix & -0.238 & 0.098 & $\mathrm{~ns}$ & -0.622 & -0.078 & $*$ \\
Coarse sand vs. gravel+silt/clay & 0.195 & 0.705 & $*$ & 0.455 & 1.605 & $*$ \\
\hline
\end{tabular}

* significant. ns not significant

Table 2.4. Odds ratios and $95 \%$ Confidence Intervals ( $\mathrm{Cl})$ for small vs. large ammocoete habitat selection.

\begin{tabular}{lcccl}
\hline Habitat type & Odds ratios & Lower Cl & Upper Cl & \\
\hline Gravel+silt/clay & 0.37 & 0.10 & 1.39 & $\mathrm{~ns}$ \\
Coarse sand & 2.2 & 1.30 & 3.71 & $*$ \\
Organic debris & 0.9 & 0.61 & 1.31 & $\mathrm{~ns}$ \\
SCS mix & 2.63 & 1.11 & 6.24 & $*$ \\
\hline
\end{tabular}

* significant. ns not significant 


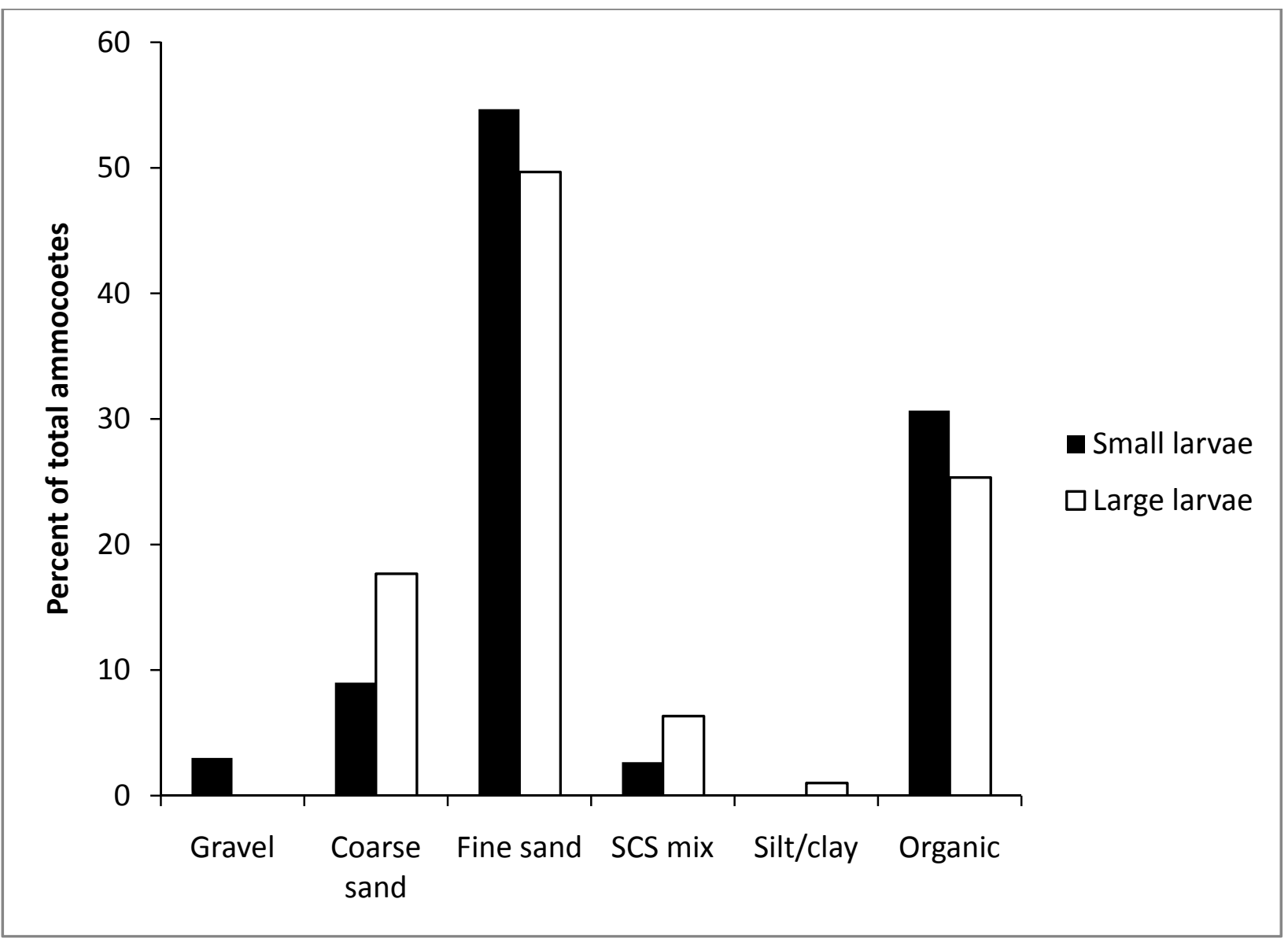

Figure 2.1. Percentages of small $(<50 \mathrm{~mm})$ and large $(100-150 \mathrm{~mm})$ ammocoetes that selected each equally-available habitat type. "SCS Mix" indicates the silt/clay/sand mixture habitat. Dark bars represent the \% of small ammocoetes, while white bars represent the \% of large ammocoetes. 


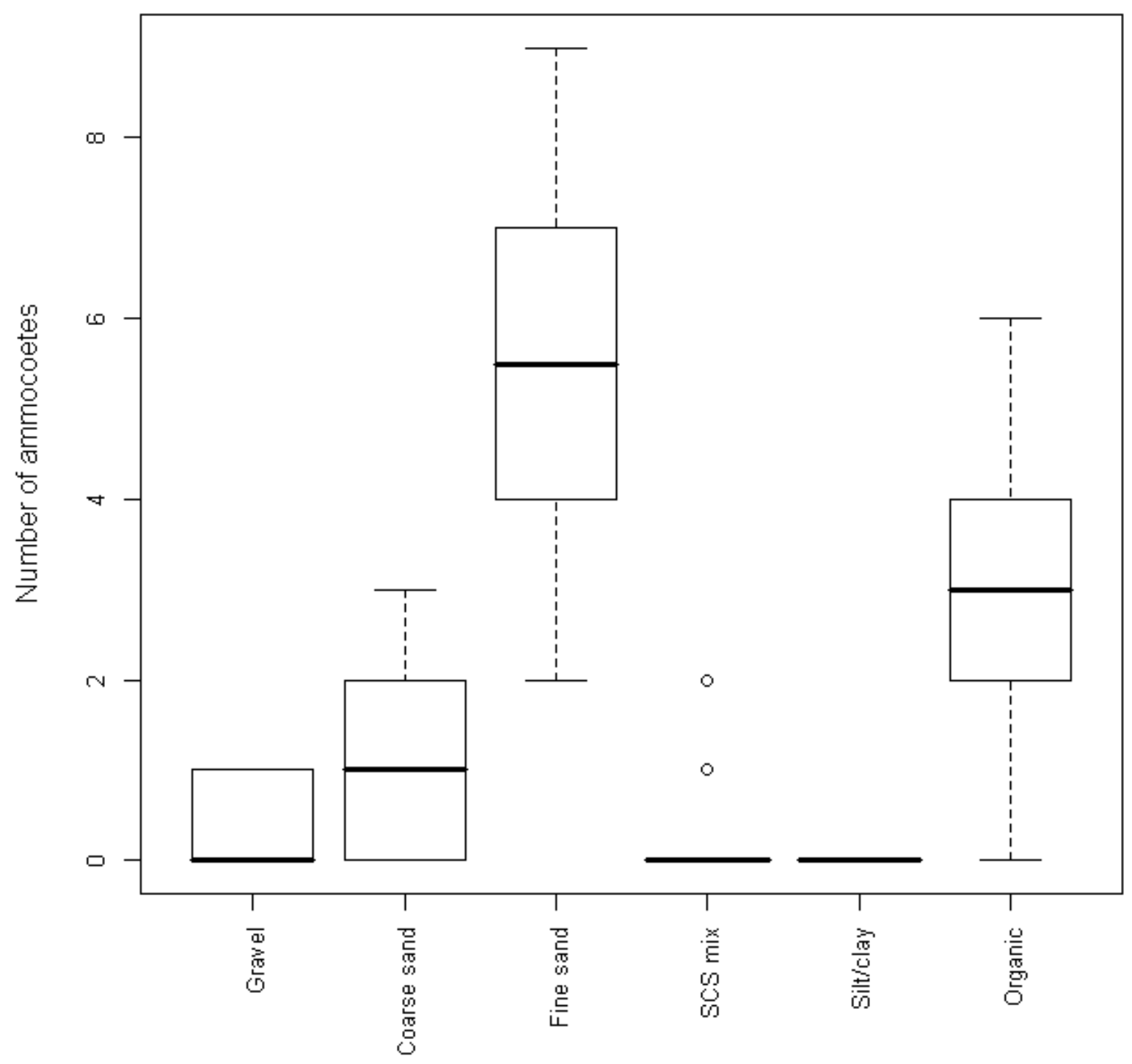

Figure 2.2. Median numbers (smallest observation, lower quartile, upper quartile, and largest observation) per trial of small ammocoetes that selected each of six equally-available habitat types. "SCS mix" represents the silt/clay/sand mixture. Open circles represent influential observations (outliers). 


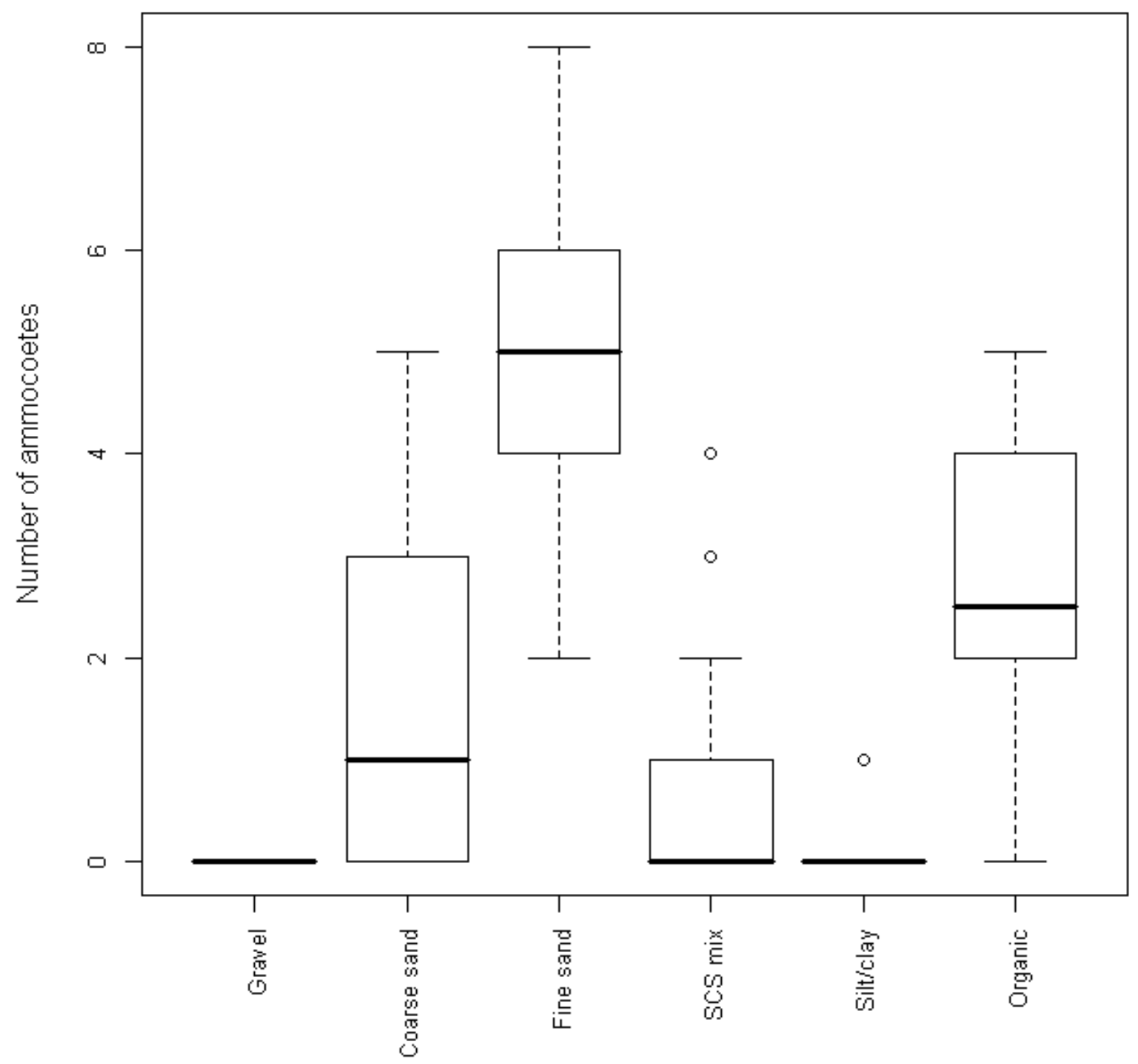

Figure 2.3. Median numbers (smallest observation, lower quartile, upper quartile, largest observation) per trial of large ammocoetes that selected each of six equally-available habitat types. "SCS mix" represents the silt/clay/sand mixture. Open circles represent influential observations (outliers). 


\title{
Chapter 3: The influence of habitat availability on predation risk in larval lampreys
}

\begin{abstract}
Stream sedimentation and channelization alter benthic habitat and impact fish populations through loss of refuge habitat and associated increase in predation risk. Understanding links among predation risk, habitat availability, and habitat stressors may be critical for management and conservation of declining species, such as lampreys (Petromyzontidae) with burrowing larvae (ammocoetes) that are benthic habitat specialists. We experimentally examined the influence of habitat availability on predation risk of ammocoetes of the least brook lamprey (Lampetra aepyptera). Ammocoetes were placed in aquaria containing a predator species (yellow bullhead, Ameiurus natalis) and one of 3 substrates: fine sand (0.125$0.5 \mathrm{~mm}$ ), coarse sand $(0.5-1.4 \mathrm{~mm})$, or silt/clay $(<0.063 \mathrm{~mm})$. Based on 10 trials with each habitat type, survival of ammocoetes was highest in aquaria with fine sand (mean $=80 \%$ ) and lower in those with coarse sand (mean $=58 \%$ ) and silt/clay (mean $=4 \%)$. Based on experimental results, ammocoetes may bear elevated predation risk in streams with silt/clay sedimentation. Predation risk of ammocoetes may also be increased in benthic habitats with larger substrates (coarse sand or larger sizes), such as those expected in channelized streams.
\end{abstract}

\section{Introduction}

Benthic habitat provides important refuge areas for many stream fishes but is commonly altered by anthropogenic stream sedimentation and channelization. Lamprey populations are likely impacted by stream alterations, given that larvae (ammocoetes) burrow into benthic substrates for refuge and foraging habitat (Hardisty and Potter 1971; Potter 1980; Jenkins and Burkhead 1993; Moyle and Cech Jr. 2004). Once an ammocoete burrows into benthic substrate, mucus from its endostyle lines and supports the burrow by holding sediment particles in place (Sterba 1962; Hardisty and Potter 1971; Jenkins and Burkhead 1993; Beamish and Lowartz 1996). Ammocoetes rarely leave burrows in preferred habitat (Sterba 1962; Hardisty and Potter 1971; Quintella et a. 2005), where a stable burrow facilitates successful feeding and breathing by 
allowing an adequate flow of water (Hardisty and Potter 1971; Malmqvist and Bronmark 1981; Beamish and Jebbink 1994; Beamish and Lowartz 1996). Stream degradation by sedimentation or channelization reduces availability of preferred benthic habitats of fine sand (Smith 2009). Further, smaller substrate sizes associated with sedimentation or larger substrates from channelization could inhibit burrow construction and cause burrow instability and abandonment.

For benthic habitat specialists, such as larval lampreys, loss of refuge habitats impact populations in several ways, including increased risk of predation. Adult lampreys construct nests and spawn in gravel substrate of stream riffles (Hardisty and Potter 1971; Jenkins and Burkhead 1993; Moyle and Cech Jr. 2004; Jang and Lucas 2005). Newly hatched ammocoetes eventually leave the nest and are swept downstream until burrowing into the bottom in areas of low water velocity (Hardisty and Potter 1971; Potter 1980; Jenkins and Burkhead 1993; Moyle and Cech Jr. 2004). Predation is highly probable during downstream drift but is less likely after ammocoetes burrow into benthic substrate. If preferred areas of fine sand habitat are covered by silt/clay sedimentation or removed by the armoring effect of channelization, then ammocoetes may spend more time searching for optimal habitat, leading to increased predation risk.

In a previous experimental study, ammocoetes selected and preferred fine sand habitat over several alternatives (Smith 2009). In addition, ammocoetes avoided gravel, silt, and clay. Small ammocoetes $(<50 \mathrm{~mm})$ avoided coarse sand, while large ammocoetes $(100-150 \mathrm{~mm})$ neither selected nor avoided coarse sand. Causal factors of habitat selection by ammocoetes are unclear, but possibly relate to burrow stability, feeding efficiency, and respiration. Ammocoetes may emerge from substrate at night in search of better habitat, particularly if their current burrow habitat is suboptimal (Hardisty and Potter 1971; Reynolds and Casterlin 1979; Potter 1980; Sugiyama and Goto 2002; Torgensen and Close 2004; Quintella et. al 2005). If so, then 
ammocoetes may increase their vulnerability to predation. Based on our literature review, we focused research efforts on the relationship between habitat availability and predation risk in larval lampreys. Specifically, we predicted that burrow abandonment at night in response to suboptimal (nonpreferred) habitat would increase predation risk of larval lampreys.

The relationship between habitat availability and predation is previously undocumented for larval lampreys but may be critical to the management and conservation of lamprey populations. Stream sedimentation is a leading cause of stream habitat degradation (Kohler and Hubert 1999) and may be linked to loss of preferred habitat and diminished lamprey populations. Also, stream channelization alters habitat by increasing water flow and the size of benthic substrate, as well as reducing slow-velocity depositional areas and fine sand habitat (Kohler and Hubert 1999). Habitat alteration is often assumed to influence fish populations, but experimental studies are needed for strong inference. The objective of this study was to test for differences in predation on least brook lampreys in preferred and non-preferred habitat types.

\section{Methods}

\section{Aquaria setup}

For this study, we used six $246 \mathrm{~L}$ (65 gal.) glass aquaria (91.5 cm x $45.8 \mathrm{~cm}$ x $53 \mathrm{~cm}$ ); three treatment tanks and three control tanks. A sequence pump $(2.6 \mathrm{~L} / \mathrm{min})$ recirculated water from a $379 \mathrm{~L}$ sump to the aquaria. Water quality was maintained with carbon filters, bio balls, and fresh water substitutions. Water temperature varied from $15.1-16.7^{\circ} \mathrm{C}$ throughout the study. Photoperiod (12 hr light, $12 \mathrm{hr}$ dark) was maintained with wide spectrum fluorescent plant bulbs and an electric timer. 
Each aquarium contained a single substrate type (10 cm deep) in one large plastic container (90 cm x $44 \mathrm{~cm}$ x $15 \mathrm{~cm}$ ). We chose three substrate habitat categories based on results from a previous experiment on habitat selection in large ammocoetes (Smith 2009), in which fine sand was the preferred substrate, coarse sand was not selected for or against, and silt/clay substrate was selected against. Fine sand, coarse sand, and silt/clay were the highest, intermediate, and least selected substrate types from the habitat selection experiment. Fine sand $(0.125-0.5 \mathrm{~mm})$ was placed in one treatment tank and one control tank, coarse sand $(0.5-1.4$ $\mathrm{mm})$ in one treatment tank and one control tank, and clay/silt $(<0.063 \mathrm{~mm})$ in one treatment tank and one control tank.

\section{Experimental Design and Analysis}

This study was designed to examine the relationship between substrate availability and predation on large ammocoetes $(100-120 \mathrm{~mm})$ of least brook lamprey. In each of the six aquaria, 20 ammocoetes were released at the beginning of each trial. After allowing 24 hours for ammocoetes to burrow into the substrate, we released 2 adult yellow bullheads (Ameiurus natalis) (293 - $319 \mathrm{~mm}$ TL) into each treatment tank. The bullheads were fed ad libidum in captivity, but starved for 2 days before release into treatment tanks. Bullheads were not placed in control aquaria. Six days after the release of bullheads into treatment tanks, substrate trays were removed from three treatment and three control tanks and the number of surviving ammocoetes were counted from each tank. This process was conducted 10 times for a total of 10 trials from 23 July 2008 to 1 October 2008. The ratio of the initial to final counts of individuals is an estimate of survival and served as a proxy for predation risk. Given the short duration of 
our experimental trials, we assumed that the absence of lampreys after each trial represented mortality associated with predation. We used binomial logistic regression to calculate odds ratios for the survival of ammocoetes in different habitats and tested if odds ratios of survival differed significantly between different substrate types (Dobson and Barnett 2008). A Bonferroni correction was applied to account for 3 separate comparisons making the individual comparison alpha equal to $0.05 / 3(0.016)$. This allowed the familywise alpha to be set to 0.05 . In addition, confidence intervals (95 \%) were calculated for the odds ratios.

\section{Results}

Survival of 20 ammocoetes in each of 10 trials ranged from 10 to 20 individuals in the aquarium with fine sand, 5 to 18 in coarse sand, and 0 to 2 in silt/clay (Figure 3.1). With data from the 10 trials pooled, survival rates of ammocoetes were highest for fine sand (mean = $80 \%$ ) followed by those of coarse sand (mean $=58 \%$ ) and clay $/$ silt $($ mean $=4 \%)($ Figure 3.2, Table 3.1). Survival of ammocoetes was $100 \%$ in all control tanks.

Based on the binomial logistic regression model, ammocoete survival differed significantly between each pair of substrate types (Table 3.2). Further, the odds ratio for fine sand vs. clay/silt was 142.72, indicating that ammocoetes were over 142 times as likely to survive in fine sand vs. clay/silt (Table 3.2; Dobson and Barnett 2008). Ammocoetes were 43 times as likely to survive in coarse sand vs. clay/silt, and 3 times as likely to survive in fine sand vs. coarse sand (Table 3.2). Confidence intervals calculated for odds ratios also indicated significance for all habitat comparisons by the exclusion of zero in the intervals (Table 3.3). 
A few observational results supplement the experimental findings. First, ammocoetes successfully burrowed into silt/clay, fine sand, and coarse sand habitats in aquaria. Depth and shape of burrows were not quantified, but we observed slower burrowing times for silt/clay relative to sand habitats. Ammocoetes were most often outside of burrows at night, where observations of ammocoete activity were assisted by flashlight or video camera with an infrared illuminator. Catfish depredation of swimming ammocoetes was observed, but catfish were never observed rooting in the substrate, nor was there any sign of this type of activity (i.e. increased turbidity or disturbed substrate). Ammocoetes were observed swimming in the water column of tanks with silt/clay and coarse sand substrates, but not in those with fine sand substrate.

\section{Discussion}

Our study demonstrated a predation-induced decrease in ammocoete survival when benthic substrate was too small (silt/clay, mean survival of 4\%) or too large (coarse sand, mean survival of 58\%) relative to the preferred substrate of fine sand (mean survival of $80 \%$ ). This is likely linked to substrate size and its influence on the construction and stability of burrows. Ammocoetes within burrows are protected from most predators, but ammocoetes are expected to spend more time outside of burrows when optimal burrow habitat is limited or unavailable. Hence, the probability of predation risk increases when preferred habitat is unavailable. Our laboratory results are likely transferable to stream systems. The availability of fine sand habitat is often reduced in altered streams, with an increase in silt/clay substrate associated with stream sedimentation and an increase in larger substrates in channelized streams.

Fine sand habitat preferred by ammocoetes is likely to be patchy owing to depositional 
patterns of stream systems (Komar and Carling 1991; Powell 1998) and will be limited in some streams that are not degraded. Availability of fine sand habitat is controlled, in part, by geology, and often increases with stream size. However, ammocoetes of Lampetra aepyptera often occur in smaller streams, where preferred habitat is limited and could be reduced by minimal sedimentation or channelization. If our laboratory results transfer to stream settings, then predation could cause dramatic declines in lamprey populations within degraded streams. Although we demonstrated a relationship between habitat availability and predation risk in least brook lamprey, the results may not be applicable to other species of lamprey.

Many studies have shown that habitat selection directly influences an animal's fitness (Stein and Magnuson 1976; Pierce 1988; Main 1987; Wahle and Steneck 1992; Jordan et al. 1996; Smith and Smith 2001; Haas et al. 2004), including growth and survival (Holomuzki 1986, Railsback and Harvey 2002; Railsback et al. 2003). Ammocoetes may choose fine sand habitat for its construction properties in building stable burrows (Beamish and Jebbink 1994; Beamish and Lowartz 1996). Stable burrows facilitate growth through successful filter-feeding and respiration by allowing an adequate flow of water. Reduced risk of predation resulting from remaining in a burrow is likely an artifact from selection of optimal burrow habitat. If an ammocoete's ability to feed or respire successfully becomes inhibited due to an inability to construct and maintain an adequate burrow, it might be prompted to emerge at night to search for better substrate (Hardisty and Potter 1971; Quintella et al. 2005). It is during this emergence to search for habitat that ammocoetes most likely succumb to predation. Therefore, ammocoetes may experience higher survival in fine sand habitat simply because they are not forced to emerge as often to search for appropriate substrate. 
Silt/clay habitat was associated with the highest predation risk in our study. We attributed this to burrow abandonment within suboptimal (nonpreferred) benthic habitats. Ammocoetes were able to burrow into silt/clay habitat, but possibly were unable to either maintain burrows or adequately respire and feed. Clay and silt are very fine particles that may clog the gill lamellae of ammocoetes (Beamish and Jebbink 1994; Beamish and Lowartz 1996; Close et al. 2002). In addition, clay compaction may block ammocoete burrows and restrict flow of water and food (Beamish and Jebbink 1994; Beamish and Lowartz 1996). Another negative consequence associated with silt/clay habitat is the difficulty in initial burrowing for ammocoetes. The compactness of silt/clay substrates lengthens burrowing time. For ammocoetes trying to evade capture, predation risk increases with time necessary to complete a burrow.

Larger particles like coarse sand may inhibit construction and maintenance of burrows (Beamish and Jebbink 1994; Beamish and Lowartz 1996), particularly for smaller ammocoetes (Smith 2009). Burrows in coarse sand could be prone to collapse, because stability of mucussupported burrow walls is expected to decline as particle size increases (Beamish and Jebbink 1994; Beamish and Lowartz 1996). Smith (2009) found that large ammocoetes (100 - $150 \mathrm{~mm})$ did not select or avoid coarse sand, but smaller ammocoetes $(<50 \mathrm{~mm})$ avoided coarse sand. In the predation risk study, most large ammocoetes (58\% mean survival) reduced predation risk by their ability to construct and remain inside of stable burrows. Although not used in the predation risk study, smaller ammocoetes $(<50 \mathrm{~mm}$ ) would likely experience higher predation risk in coarse sand habitat given their avoidance of coarse sand in habitat selection studies.

Global declines of lamprey populations have grabbed the attention of natural resource agencies, but many aspects of lamprey ecology are poorly understood. As with many stream 
fishes, habitat degradation is a likely cause of population declines (Jenkins and Burkhead 1993;

Renaud 1997; Kohler and Hubert 1999; Close et al. 2002; Moyle and Cech Jr. 2004).

Sedimentation and channelization are two common anthropogenic alterations to streams that may greatly affect ammocoete habitat. Both processes degrade ammocoete habitat by altering the natural substrate regime in streams. Sedimentation results from many land use practices, such as timber removal, road construction, riparian removal, agricultural activities, and urban development. Sedimentation often increases the amounts of clay and silt particles within a stream (Jenkins and Burkhead 1993; Kohler and Hubert 1999; Close et al. 2002). Clay and silt from sedimentation can blanket and reduce clean fine sand habitat. Channelization removes natural stream meanders and often increases the size of benthic substrate in streams because of increased stream velocities and reduced formation of fine sand beds (Jenkins and Burkhead 1993; Kohler and Hubert 1999; Close et al. 2002).

Our study links habitat availability and predation risk in ammocoetes of the least brook lamprey. Land use practices that reduce fine sand substrate in streams and increase silt/clay and coarse sand may increase predation risk of ammocoetes. Given that loss of habitat is a likely explanation for population declines in lamprey species, our results have conservation and management implications. Specifically, we found that substrates too small (silt/clay) or too large (coarse sand) are associated with higher predation than the preferred fine sand substrate. Possibly, the preferred fine sand substrate is just right for burrow construction and stability (Beamish and Jebbink 1994, Beamish and Lowartz 1996), and when presented with suboptimal substrates (too large or too small) ammocoetes may bear increased predation risk due to an increase in time spent outside of burrows. Availability of fine sand habitat is controlled, in part, by geology and stream size but can be reduced by habitat alterations, such as stream 
sedimentation and channelization. If stream habitat alterations reduce fine sand habitat, then

populations of least brook lamprey will likely decline owing, in part, to increased predation risk.

\section{Literature Cited}

Beamish, F. W. H., and Jebbink, J. 1994. Abundance of lamprey larvae and physical habitat. Env. Biol. Fishes, 39: 209 - 214.

Beamish, F. W. H., and Lowartz, S. 1996. Larval habitat of American brook lamprey. Can. J. Fish. Aquat. Sci. 53:693 - 700.

Close, D. A., Fitzpatrick, M. S., and Li, H. W. 2002. The ecological and cultural importance of a species at risk of extinction, pacific lamprey. Fisheries, 27: 19-25.

Dobson, A. J., and Barnett, A. G. 2008. An introduction to generalized linear models. CRC Press,Boca Raton, Florida.

Haas, H. L., Rose, K. A., Fry, B., Minello, T. J., Rozas, L. P. 2004. Brown shrimp on the edge: Linking habitat to survival using an individual based simulation model. Ecol. Appl. 14: $1232-1247$.

Hardisty, M. W., and Potter, I. C. 1971. The biology of lampreys. Vol. 1. Edited by M. W. Hardisty and I. C. Potter. Academic Press, London.

Holomuzki, J. R. 1986. Effect of microhabitat on fitness components of larval tiger salamanders, Ambystoma tigrinum nebulosum. Oecologia, 71: 142 - 148.

Jang, M. H., and Lucas, M. C. 2005. Reproductive ecology of the river lamprey. J. of Fish Biol. 66: 499 - 512 .

Jenkins, R. E., and Burkhead, N. M. 1993. Freshwater fishes of Virginia. American Fisheries Society, Bethesda, Maryland.

Jordan, F., Bartolini, M., Nelson, C., Patterson, P. E., and Soulen, H. L. 1996. Risk of predation affects habitat selection by the pinfish Lagodon rhomboides (Linnaeus). J. Exp. Mar. Biol. Ecol. 208: 45 - 56.

Kohler, C. C., and Hubert, W. A., editors. 1999. Inland fisheries management in North America, $2^{\text {nd }}$ edition. American Fisheries Society, Bethesda, Maryland.

Komar, P. D. and P. A. Carling. 1991. Grain sorting in gravel-bed streams and the choices of particle sizes for flow-competence evaluations. Sedimentology, 38:489-502. 
Main, K. L. 1987. Predator avoidance in seagrass meadows: Prey behavior, microhabitat selection, and cryptic coloration. Ecology, 68: 170 - 180.

Malmqvist, B., and Bronmark, C. 1981. Filter feeding in larval Lampetra planeri: effects of size, temperature, and particle concentration. Oikos, 38: 40 - 46.

Moyle, P. B., and Cech Jr., J. J. 2004. Fishes an introduction to ichthyology. Pearson Education, Upper Saddle River, New Jersey.

Pierce, C. L. 1988. Predator avoidance, microhabitat shift, and risk sensitive foraging in larval dragonflies. Oecologia, 77: $81-90$.

Potter, I. C. 1980. Ecology of larval and metamorphosing lampreys. Can. J. Fish. Aquat. Sci. 37: $1641-1657$.

Powell, D. M. 1998. Patterns and processes of sediment sorting in gravel-bed rivers. Prog. Phys. Geog. 22:1-32.

Quintella, B. R., Andrade, N. O., Espanhol, R., and Almeida, P. R. 2005. The use of PIT telemetry to study movements of ammocoetes and metamorphosing sea lampreys in river beds. J. Fish Biol. 66: 97 - 106.

Railsback, S. F., and Harvey, B. C. 2002. Analysis of habitat selection rules using an individual based model. Ecology, 83: $1817-1830$.

Railsback, S. F., Stauffer, H. B., and Harvey, B. C. 2003. What can habitat preference models tell us? Tests using a virtual trout population. Ecol. Appl.. 13: 1580 - 1594.

Renaud, C. B. 1997. Conservation status of northern hemisphere lampreys (Petromyzontidae). J. Appl. Ichthyol. 13: $143-148$.

Reynolds, W. W., and Casterlin, M. E. 1979. Photokinetic responses and diel activity of sea lamprey Petromyzon marinus ammocoete larvae. J. Fish. Biol. 14: 425 - 428.

Seversmith, H. F. 1953. Distribution, morphology, and life history of Lampetra aepyptera, a brook lamprey, in Maryland. Copeia, 1953: 225 - 232.

Sponaugle, S., and Lawton, P. 1990. Portunid crab predation on juvenile hard clams: effects of substrate type on prey density. Mar. Ecol. Prog. Ser. 67: 43 - 53.

Smith, D.M. 2009. Habitat selection and predation risk in larval lampreys. M.S. thesis, West Virginia University, Morgantown, West Virginia.

Smith, R. L., and Smith, T. M. 2001. Life history patterns. In Ecology and field biology. Edited by R. L. Smith and T. M. Smith. Benjamin Cummings, New York. pp. 236 - 239.

Stein, R. A, and Magnuson, J. J. 1976. Behavioral response of crayfish to a fish predator. Ecology, 57: $751-761$. 
Sterba, G. 1962. Die Neunaugen (Petromyzontidae). In Handbuch der Binnenfischerei Mitteleuropas. Vol. 3. Edited by R. Demoll and H. N. Maier. E. Schweizerbart'sche, Verlagsbuchhandlung, Stuttgart, Germany. pp. 263 -352.

Sugiyama, H., and Goto, A. 2002. Habitat selection by larvae of a fluvial lamprey, Lethenteron reissneri, in a small stream and an experimental aquarium. Icthyol. Res. 49: $62-68$.

Torgensen, C. E., and Close, D. A. 2004. Influence of habitat heterogeneity on the distribution of larval pacific lamprey (Lampetra tridenta) at two spatial scales. Fresh. Biol. 49: 614 -630 .

Wahle, R. A., and Steneck, R. S. 1992. Habitat restrictions in early benthic life: experiments on habitat selection and in situ predation with the American lobster. J. Exp. Mar. Biol. Ecol. 157: $91-114$. 
Table 3.1. Overall survival of ammocoetes in each habitat type ( 10 trials pooled per habitat type).

\begin{tabular}{lcccc} 
Habitat & \# Lived & \# Died & \% Survivors & 95 \% Profile Likelihood Confidence Interval \\
\hline clay/silt & 8 & 192 & 4.0 & $2.4-5.6$ \\
coarse sand & 115 & 85 & 57.5 & $51.8-63.3$ \\
fine sand & 160 & 40 & 80.0 & $75.1-84.9$ \\
\hline
\end{tabular}

Table 3.2. Comparisons of ammocoete survival from predation in different habitat types and the odds of survival in one habitat versus another.

\begin{tabular}{lccccccc}
\hline Habitat Comparison & Estimate & Std. Error & $z$ value & $\operatorname{Pr}(>|z|)$ & Odds Ratio \\
\hline Coarse Sand vs. Clay/Silt & 3.77 & 0.41 & 9.24 & $<2 \mathrm{E}-16$ & 43.36 & $*$ \\
Fine Sand vs. Clay/Silt & 4.96 & 0.43 & 11.56 & $<2 \mathrm{E}-16$ & 142.72 & $*$ \\
Fine Sand vs. Coarse Sand & 1.19 & 0.24 & 4.96 & $6.96 \mathrm{E}-07$ & 3.29 & $*$ \\
\hline$*$
\end{tabular}

* significant at $\alpha=0.05$

Table 3.3. The odds of ammocoetes surviving predation in a given habitat vs. another habitat and the associated $95 \%$ confidence intervals.

\begin{tabular}{lcccc}
\hline & & & & \\
& Odds Ratio & Lower Cl & Upper Cl & \\
\cline { 1 - 4 } Coarse sand vs. Clay/silt & 43.36 & 16.32 & 115.19 & $*$ \\
Fine sand vs. Clay/silt & 142.72 & 51.1 & 398.63 & $*$ \\
Fine sand vs. Coarse sand & 3.29 & 1.85 & 5.85 & $*$
\end{tabular}

* significant 


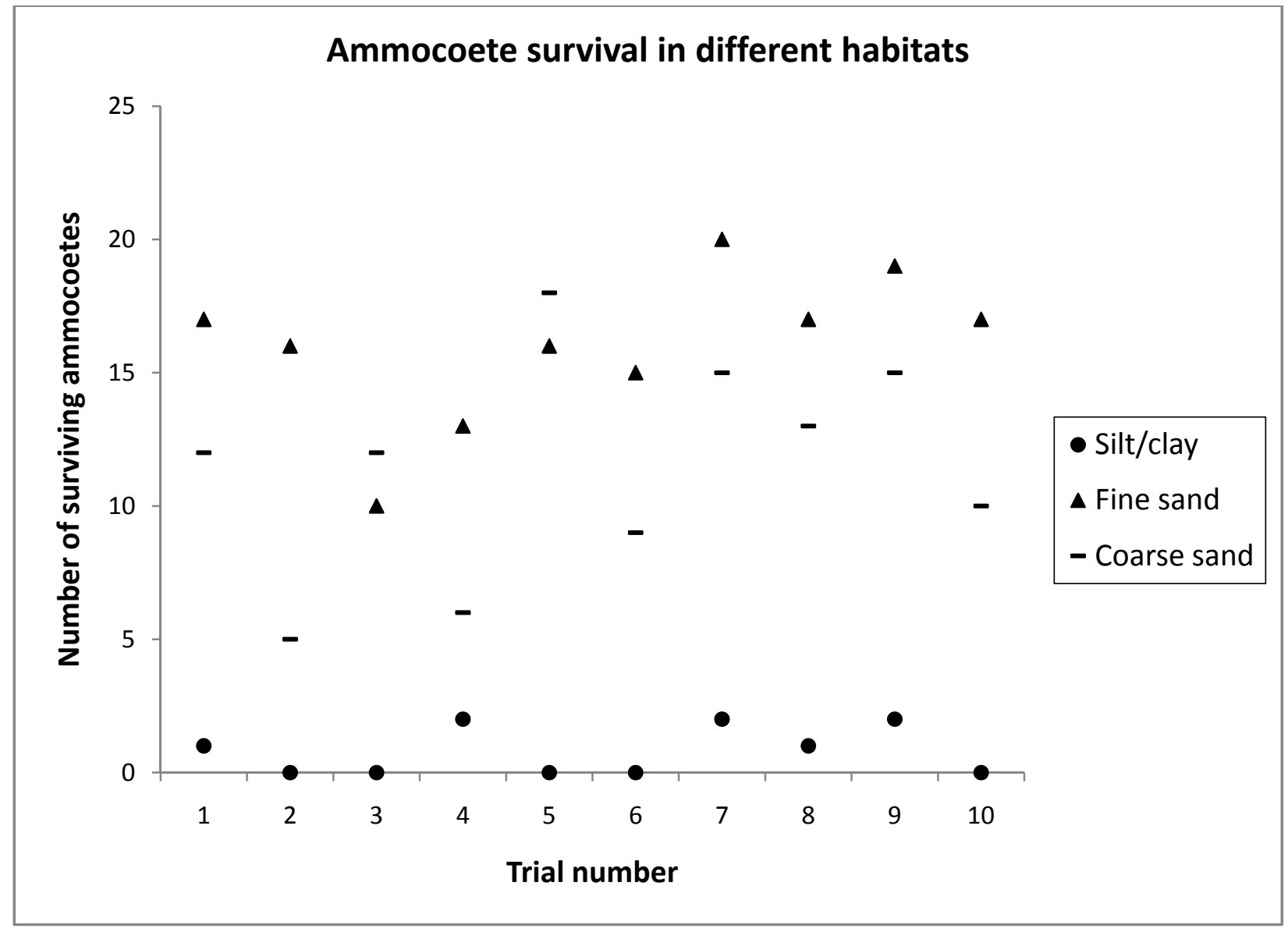

Figure 3.1. Summary of experimental trials showing number of surviving ammocoetes in each habitat per trial. Twenty ammocoetes were present at the start of each trial. 


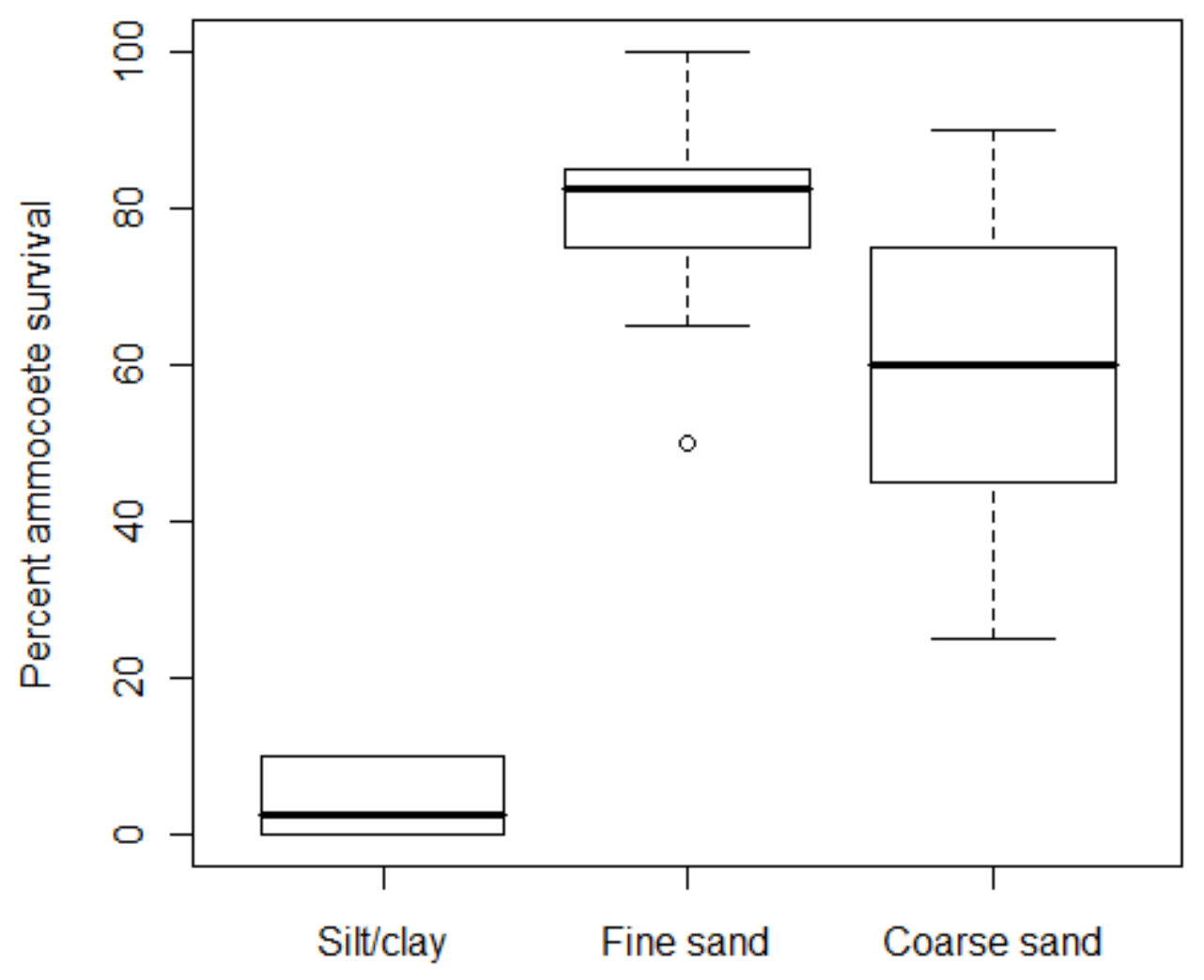

Figure 3.2. Median percentage survival (smallest observation, lower quartile, upper quartile, and largest observation) per trial for each habitat type. Open circles represent influential observations (outliers).

John

$\mathrm{H}$. 